\title{
Synthesis of Pterocellin A
}

Meaghan M. O’Malley, Fehmi Damkaci and T. Ross Kelly*

E. F. Merkert Chemistry Center, Boston College, Chestnut Hill, Massachusetts 02467

ross.kelly@bc.edu

\section{Supporting Information}

\section{Table of Contents:}

pp. S2 - S12 Experimental procedures for the synthesis of 1, 3, 7, 8, 9, 10, 12, 13, 14, 15, 16.

pp. S13 - S35 $\quad{ }^{1}$ H NMR and ${ }^{13} \mathrm{C}$ NMR spectra of $\mathbf{1}, \mathbf{7}, \mathbf{8}, \mathbf{9}, \mathbf{1 0}, \mathbf{1 2}, \mathbf{1 3}, \mathbf{1 4}, \mathbf{1 5}, \mathbf{1 6}$ and ${ }^{1} \mathrm{H}$ NMR spectra for 3. 
General Procedures: The reaction solvents tetrahydrofuran (THF), diethyl ether and dichloromethane (DCM) were dried by passage through activated alumina columns. ${ }^{1}$ Anhydrous $N, N$-dimethylformamide (DMF) was purchased from ACROS. oIodoxybenzoic acid (IBX) was made using Dess and Martin's procedure. ${ }^{2}$ tertButyllithium was titrated prior to use. ${ }^{3}$ All other reagents were used as received from the manufacturer unless otherwise stated. Preparative thin layer chromatography (TLC) was performed on EM Science silica gel 60500 -micron $(20 \times 20 \mathrm{~cm})$ plates or 250 micron (20 x $20 \mathrm{~cm}$ ) plates; compounds were extracted off the silica by stirring with an appropriate solvent mixture. Flash chromatography was carried out using Bodman reagent silica gel 60A (32 - 63 micron). Medium pressure liquid chromatography (MPLC) was carried out using a Biotage Horizon HPFC $^{\mathrm{TM}}$ system with pre-packed KPsilica gel $60 \AA$ (32 - 63 micron) cartridges. Reactions were monitored by analytical TLC using Whatman 250 micron silica gel plates with aluminum backing. All TLC plates were visualized by UV fluorescence quenching. Rotary evaporation was normally carried out at a pressure of ca. 6 torr using a diaphragm vacuum pump. Melting points were recorded on a Mel-Temp ${ }^{\text {TM }}$ melting point apparatus and are uncorrected. ${ }^{1} \mathrm{H}$ NMR spectra were recorded on a Varian Gemini-400 (400 MHz) spectrometer and are reported in ppm using TMS (0.00 ppm) or solvent (chloroform $=7.26 \mathrm{ppm}$; DMSO- $\mathrm{d}_{5}=2.50 \mathrm{ppm}$ ) as an internal standard. Data are reported as: $[\delta \operatorname{shift}]([\mathrm{s}=$ singlet, $\mathrm{d}=$ doublet, $\mathrm{t}=$ triplet, $\mathrm{dd}=$ doublet of doublets, $\mathrm{b}=$ broad, $\mathrm{m}=$ multiplet], $[J=$ coupling constant in $\mathrm{Hz}]$ and [integration]). Proton decoupled ${ }^{13} \mathrm{C}$ NMR spectra were recorded on a Varian Gemini-400 (100 MHz) spectrometer and are reported in ppm using solvent (chloroform- $\mathrm{d}_{1}=77.0 \mathrm{ppm}$; DMSO- $\mathrm{d}_{6}=39.5 \mathrm{ppm}$ ) as an internal standard. High resolution mass spectra were obtained at the University of Illinois at the Urbana Champaign School of Chemical Science and at the Boston College Chemistry Department. Infrared spectra were recorded using a Nicolet Avatar 360 FT-IR and are reported in $\mathrm{cm}^{-1}$. UV-visible spectra were recorded on an Agilent 8453 spectrophotometer (190 - $1100 \mathrm{~nm}$ range) and are reported in $\mathrm{nm}$.

1. Pangborn, A. B.; Giardello, M. A.; Grubbs, R. H.; Rosen, R. K.; Timmers, F. J. Organometallics 1996, 15, 1518-1520.

2. Dess, D. B.; Martin, J. C. J. Org. Chem. 1983, 48, 4155-4156.

3. Duhamel, L; Plaquevent, J. J. Organomet. Chem. 1993, 448, 1-3. 


\section{2-(Hydroxymethyl)-5-methoxy-4H-pyran-4-one (7)}

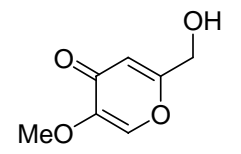

To a solution of $\mathrm{KOH}(2.18 \mathrm{~g}, 38.9 \mathrm{mmol}, 1.10$ equiv) in water $(21.8 \mathrm{~mL})$ was added kojic acid (6) (5.02 g, $35.3 \mathrm{mmol}, 1.00$ equiv). Once all the kojic acid dissolved the solution was kept at $20^{\circ} \mathrm{C}$ in a cool water bath and dimethyl sulfate ( $4.45 \mathrm{~g}, 35.3 \mathrm{mmol}, 1.00$ equiv) was added slowly over the course of 30 min. The solution was then stirred at $20^{\circ} \mathrm{C}$ for $1 \mathrm{~h}$. The resulting suspension was kept at $-20{ }^{\circ} \mathrm{C}$ overnight and the solid was filtered under vacuum; the solid was dried in vacuo to afford 7 (4.29 g, 78\%) as a light yellow solid: mp $161.5-163.5{ }^{\circ} \mathrm{C}$, lit. ${ }^{4} 161{ }^{\circ} \mathrm{C} ;{ }^{1} \mathrm{H}$ NMR (400 MHz, DMSO-d $\left.{ }_{6}\right) \delta 3.64$ (s, 3H), 4.29 (d, $\left.J=5.9 \mathrm{~Hz}, 2 \mathrm{H}\right), 5.68$ (t, $\left.J=5.9 \mathrm{~Hz}, 1 \mathrm{H}\right)$, $6.29(\mathrm{~s}, 1 \mathrm{H}), 8.08(\mathrm{~s}, 1 \mathrm{H}) ;{ }^{13} \mathrm{C}$ NMR $\left(100 \mathrm{MHz}, \mathrm{DMSO}-\mathrm{d}_{6}\right) \delta 56.1,59.3,110.6,138.8$, 147.7, 167.7, 172.5; IR (KBr) v 3183, 3079, 2842, 1638, $1694 \mathrm{~cm}^{-1}$; HRMS (ESI) $\mathrm{m} / \mathrm{z}$ calcd for $\mathrm{C}_{7} \mathrm{H}_{8} \mathrm{O}_{4} \mathrm{Na} 179.0320(\mathrm{M}+\mathrm{Na})^{+}$, found 179.0311.

\section{2-(Hydroxymethyl)-5-methoxypyridin-4(1H)-one (8)}

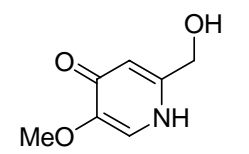

To a sealable tube were added 7 ( $3.98 \mathrm{~g}, 25.5 \mathrm{mmol}, 1.00$ equiv) and conc. $\mathrm{NH}_{4} \mathrm{OH}$ (5.53 mL, $142 \mathrm{mmol}, 5.60$ equiv). The tube was sealed and heated at $90{ }^{\circ} \mathrm{C}$ for $2 \mathrm{~h}$. The reaction was then cooled to room temperature and filtered, washing with methanol; the combined filtrate and washes were concentrated in vacuo. The residue was dissolved in methanol and refluxed for 30 min with Darco ${ }^{\circledR}$ activated carbon. The suspension was filtered through Celite and the solvent was removed in vacuo. The residue was then dissolved a second time in methanol and refluxed with Darco ${ }^{\circledR}$ activated carbon for 30 min before filtering it once more through Celite and removing the remaining solvents in vacuo to yield $8(3.26 \mathrm{~g}, 82 \%)$ as a brown solid that was ordinarily used in the next step without further purification. Analytically pure material was obtained through purification by preparative thin layer chromatography eluting with 1:1 methanol/DCM and extracting with methanol: mp $171-173^{\circ} \mathrm{C}$, lit. ${ }^{5} 173$ - $175{ }^{\circ} \mathrm{C} ;{ }^{1} \mathrm{H}$ NMR (400 MHz, DMSO-d 6 ) $\delta 3.66$ (s, 3H), 4.37 (s, 2H), 6.24 (b, 1H),

4. Campbell, K. N.; Ackerman, J.F.; Campbell, B. K. J. Org. Chem. 1950, 15, 221-226.

5. Armit, J. W.; Nolan, T. J. J. Chem. Soc. 1931, 3023-3031. 
$7.40(\mathrm{~b}, 1 \mathrm{H}), \mathrm{NH}$ and $\mathrm{OH}$ proton peaks are too broad to be seen; ${ }^{13} \mathrm{C}$ NMR $(100 \mathrm{MHz}$, DMSO-d $\left._{6}\right) \delta 56.0,60.0,110.6,120.9,147.8,149.3,169.0$; IR (KBr) v 3439, 3283, 3186, 1624, $1565 \mathrm{~cm}^{-1}$; HRMS (ESI) $\mathrm{m} / \mathrm{z}$ calcd for $\mathrm{C}_{7} \mathrm{H}_{10} \mathrm{NO}_{3} 156.0661(\mathrm{M}+\mathrm{H})^{+}$, found 156.0664 .

\section{[5-Methoxy-4-(4-methoxybenzyloxy)pyridin-2-yl]methanol (9)}

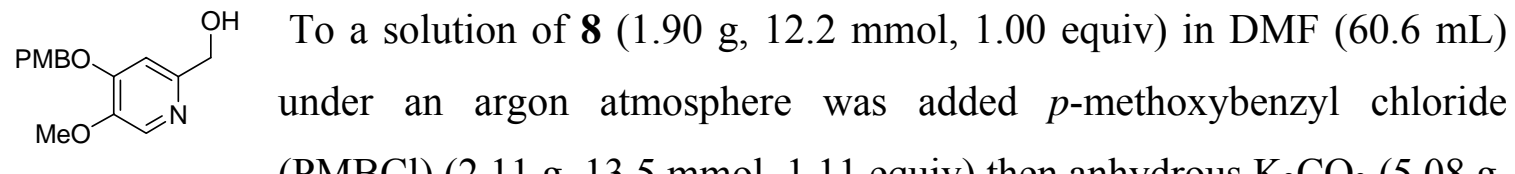
(PMBCl) (2.11 g, $13.5 \mathrm{mmol}, 1.11$ equiv) then anhydrous $\mathrm{K}_{2} \mathrm{CO}_{3}(5.08 \mathrm{~g}$, $36.7 \mathrm{mmol}, 3.01$ equiv) in that order. The reaction was stirred at room temperature for 2 $\mathrm{h}$, then heated at $80{ }^{\circ} \mathrm{C}$ for $3 \mathrm{~h}$. The reaction was then poured into water $(100 \mathrm{~mL})$ and extracted with ethyl acetate $(3 \times 100 \mathrm{~mL})$. The combined extracts were washed with water $(1 \times 100 \mathrm{~mL})$ and brine $(1 \times 100 \mathrm{~mL})$, then dried over $\mathrm{MgSO}_{4}$. Solvents were removed in vacuo and the residue was dissolved in $2 \mathrm{~N} \mathrm{HCl}(50 \mathrm{~mL})$ and washed with ethyl acetate $(50 \mathrm{~mL})$. The layers were separated and the organic layer was extracted with $2 \mathrm{~N} \mathrm{HCl}(1 \times 50 \mathrm{~mL})$. The combined aqueous phases were basified to $\mathrm{pH} 9$ with solid $\mathrm{K}_{2} \mathrm{CO}_{3}$. The aqueous layer was then extracted with ethyl acetate $(3 \times 50 \mathrm{~mL})$ and the combined organic extracts were washed with brine $(1 \times 100 \mathrm{~mL})$ before being dried over $\mathrm{MgSO}_{4}$. Removal of solvents in vacuo yielded 9 (1.32 g, 39\%) as a pale yellow solid. Recrystallization from DMF yielded analytically pure material: mp $139-141{ }^{\circ} \mathrm{C} ;{ }^{1} \mathrm{H}$ NMR (400 MHz, DMSO-d $)_{6} \delta 3.76(\mathrm{~s}, 3 \mathrm{H}), 3.80(\mathrm{~s}, 3 \mathrm{H}), 4.44(\mathrm{~d}, J=5.7 \mathrm{~Hz}, 2 \mathrm{H}), 5.08$ (s, 2H), 5.33 (t, $J=5.7 \mathrm{~Hz}, 1 \mathrm{H}), 6.96$ (d, $J=8.7 \mathrm{~Hz}, 2 \mathrm{H}), 7.17$ (s, 1H), 7.39 (d, $J=8.7$ $\mathrm{Hz}, 2 \mathrm{H}), 8.05(\mathrm{~s}, 1 \mathrm{H}) ;{ }^{13} \mathrm{C}$ NMR (100 MHz, DMSO-d 6 ) $\delta$ 55.1, 56.4, 64.1, 69.2, 104.6, $113.7,127.8,129.6,132.9,144.0,154.0,155.8,158.9$; IR (KBr) v 3139, 2941, 2839, 1615, $1590 \mathrm{~cm}^{-1}$; HRMS (ESI) $\mathrm{m} / \mathrm{z}$ calcd for $\mathrm{C}_{15} \mathrm{H}_{18} \mathrm{NO}_{4} 276.1236(\mathrm{M}+\mathrm{H})^{+}$, found 276.1223 . 


\section{5-Methoxy-4-(4-methoxybenzyloxy)-2-pyridinecarboxaldehyde (10)}

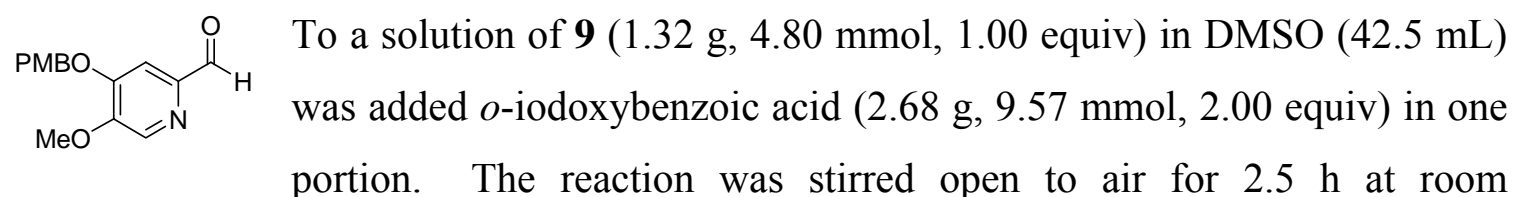

temperature, then water $(30 \mathrm{~mL})$ and ethyl acetate $(20 \mathrm{~mL})$ were added to the reaction mixture. The mixture was stirred for $10 \mathrm{~min}$ before being filtered through Celite. The layers were separated and the aqueous layer was basified to $\mathrm{pH} 10$ using solid $\mathrm{K}_{2} \mathrm{CO}_{3}$, then extracted with ethyl acetate $(3 \times 50 \mathrm{~mL})$. All organic layers were combined and washed with water $(1 \times 100 \mathrm{~mL})$ and brine $(1 \times 100 \mathrm{~mL})$ before being dried over $\mathrm{MgSO}_{4}$. Removal of solvents in vacuo yielded $\mathbf{1 0}(1.13 \mathrm{~g}, 87 \%)$ as a yellow solid. Recrystallization from chloroform resulted in yellow prisms: mp $133-135{ }^{\circ} \mathrm{C} ;{ }^{1} \mathrm{H} \mathrm{NMR}$ $\left(400 \mathrm{MHz}, \mathrm{CDCl}_{3}\right) \delta 3.82(\mathrm{~s}, 3 \mathrm{H}), 4.03(\mathrm{~s}, 3 \mathrm{H}), 5.17(\mathrm{~s}, 2 \mathrm{H}), 6.92(\mathrm{~d}, J=8.9 \mathrm{~Hz}, 2 \mathrm{H})$, $7.38(\mathrm{~d}, J=8.9 \mathrm{~Hz}, 2 \mathrm{H}), 7.57(\mathrm{~s}, 1 \mathrm{H}), 8.28(\mathrm{~s}, 1 \mathrm{H}), 9.91(\mathrm{~s}, 1 \mathrm{H}) ;{ }^{13} \mathrm{C} \mathrm{NMR}(100 \mathrm{MHz}$, $\left.\mathrm{CDCl}_{3}\right) \delta 55.5,57.0,70.8,105.5,114.3,127.1,129.5,133.5,148.1,149.2,154.5,159.8$, 192.3; IR (KBr) v 3076, 2958, 2911, 2835, $1691 \mathrm{~cm}^{-1}$; HRMS (ESI) $\mathrm{m} / \mathrm{z}$ calcd for $\mathrm{C}_{15} \mathrm{H}_{15} \mathrm{NO}_{4} \mathrm{Na} 296.0899(\mathrm{M}+\mathrm{Na})^{+}$, found 296.0899.

\section{2-Bromo-3-(methoxymethoxy)pyridine (12)}

To a solution of 2-bromo-3-pyridinol (11) $(2.00 \mathrm{~g}, 11.5 \mathrm{mmol}, 1.00$ equiv)
in dry DMF $(70 \mathrm{~mL})$ in a dry flask under an argon atmosphere was added anhydrous $\mathrm{K}_{2} \mathrm{CO}_{3}(1.59 \mathrm{~g}, 11.5 \mathrm{mmol}, 1.00$ equiv). The suspension was stirred for 15 min then cooled to $5{ }^{\circ} \mathrm{C}$ and a solution of technical grade chloromethyl methyl ether $(0.87$ $\mathrm{mL}, 12 \mathrm{mmol}, 1.0$ equiv) in dry DMF (5 mL) was added in one portion. The suspension was stirred at $5-10^{\circ} \mathrm{C}$ for $2 \mathrm{~h}$, then warmed to room temperature and stirred for $15 \mathrm{~h}$. The reaction was poured into water $(150 \mathrm{~mL})$ and extracted with diethyl ether $(4 \mathrm{x} 100 \mathrm{~mL})$, then the combined organic phases were washed with water $(1 \mathrm{x} 100 \mathrm{~mL})$ and brine $(1 \mathrm{x}$ $100 \mathrm{~mL}$ ) before being dried over $\mathrm{MgSO}_{4}$. Removal of solvents in vacuo yielded a clear oil which was purified by flash chromatography on silica gel $(4 \times 15 \mathrm{~cm})$ eluting with 1:4 ethyl acetate/hexanes to afford $12(1.71 \mathrm{~g}, 68 \%)$ as colorless crystals: $\mathrm{mp} 37-38.5{ }^{\circ} \mathrm{C} ;{ }^{1} \mathrm{H}$ 
NMR (400 MHz, DMSO-d 6 ) $\delta 3.41(\mathrm{~s}, 3 \mathrm{H}), 5.36(\mathrm{~s}, 2 \mathrm{H}), 7.40(\mathrm{dd}, J=8.2 \mathrm{~Hz}, J=4.6$ $\mathrm{Hz}, 1 \mathrm{H}), 7.60(\mathrm{dd}, J=8.2 \mathrm{~Hz}, J=1.5 \mathrm{~Hz}, 1 \mathrm{H}), 8.03(\mathrm{dd}, J=4.6 \mathrm{~Hz}, J=1.5 \mathrm{~Hz}, 1 \mathrm{H}) ;{ }^{13} \mathrm{C}$ NMR (100 MHz, DMSO-d 6 ) $\delta 56.1,94.5,123.3,124.0,132.2,142.3,149.7$; IR (KBr) v 2962, 2830, 1561, 1455, $1415 \mathrm{~cm}^{-1}$; HRMS (ESI) $\mathrm{m} / \mathrm{z}$ calcd for $\mathrm{C}_{7} \mathrm{H}_{9} \mathrm{NO}_{2} \mathrm{Br} 217.9817$ $(\mathrm{M}+\mathrm{H})^{+}$, found 217.9827 .

\section{2-Isobutyl-3-(methoxymethoxy)pyridine (13)}

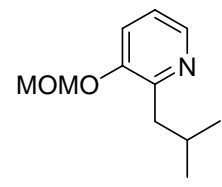

A solution of $12(0.500 \mathrm{~g}, 2.29 \mathrm{mmol}, 1.00$ equiv) in dry diethyl ether (20 $\mathrm{mL}$ ) under an argon atmosphere was cooled to $0{ }^{\circ} \mathrm{C}$, then $[1,3-$ bis(diphenylphosphino)propane]dichloronickel(II) (1.2 $\mathrm{mg}, \quad 2.2 \mu \mathrm{mol}$, 0.0010 equiv) was added. To this suspension a 2.0 M solution of isobutylmagnesium bromide ( $3.5 \mathrm{~mL}, 6.9 \mathrm{mmol}, 3.0$ equiv) in diethyl ether was added dropwise over the course of $1 \mathrm{~h}$. The solution was warmed to room temperature and stirred for $2 \mathrm{~h}$, then heated at reflux for $1 \mathrm{~h}$. After cooling to room temperature, the reaction was quenched with water (ca. $50 \mathrm{~mL}$ ), then acidified to $\mathrm{pH} 0$ using $2 \mathrm{M} \mathrm{HCl}$. The layers were separated, the aqueous layer basified to $\mathrm{pH} 10$ using solid $\mathrm{K}_{2} \mathrm{CO}_{3}$ and then extracted with diethyl ether $(3 \times 50 \mathrm{~mL})$. The organic extracts were combined, washed with water $(1 \mathrm{x}$ $100 \mathrm{~mL})$ and brine $(1 \times 100 \mathrm{~mL})$, then dried over $\mathrm{MgSO}_{4}$. Removal of solvents in vacuo yielded a brown oil which was purified by flash chromatography on silica gel $(3 \times 17 \mathrm{~cm})$ eluting with 1:4 ethyl acetate/hexanes to afford $13(0.266 \mathrm{~g}, 59 \%)$ as a light yellow oil: ${ }^{1} \mathrm{H}$ NMR (400 MHz, $\left.\mathrm{CDCl}_{3}\right) \delta 0.93(\mathrm{~d}, J=6.7 \mathrm{~Hz}, 6 \mathrm{H}), 2.14(\mathrm{~m}, 1 \mathrm{H}), 2.72(\mathrm{~d}, J=6.9$ $\mathrm{Hz}, 2 \mathrm{H}), 3.48$ (s, 3H), 5.20 (s, 2H), $7.06(\mathrm{dd}, J=8.1 \mathrm{~Hz}, J=4.9 \mathrm{~Hz}, 1 \mathrm{H}), 7.35$ (dd, $J=$ $8.1 \mathrm{~Hz}, J=1.4 \mathrm{~Hz}, 1 \mathrm{H}), 8.18(\mathrm{dd}, J=4.9 \mathrm{~Hz}, J=1.4 \mathrm{~Hz}, 1 \mathrm{H}) ;{ }^{13} \mathrm{C}$ NMR $(100 \mathrm{MHz}$, $\left.\mathrm{CDCl}_{3}\right) \delta 22.9,28.6,41.6,56.3,94.4,120.6,121.6,141.9,151.6,152.2 ; \mathrm{IR}(\mathrm{KBr})$ v 3059, 2949, 2831, $1582 \mathrm{~cm}^{-1}$; HRMS (ESI) $\mathrm{m} / z$ calcd for $\mathrm{C}_{11} \mathrm{H}_{18} \mathrm{NO}_{2} 196.1338(\mathrm{M}+\mathrm{H})^{+}$, found 196.1329. 


\section{(2-Isobutyl-3-(methoxymethoxy)pyridin-4-yl)(5-methoxy-4-(4- methoxybenzyloxy)pyridin-2-yl)methanone (14)}

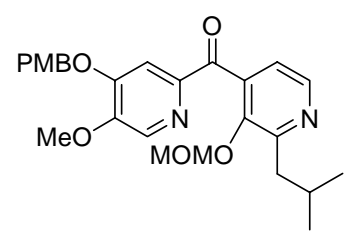

A solution of pyridine ether $13(0.736 \mathrm{~g}, 3.77 \mathrm{mmol}, 1.00$ equiv $)$ in diethyl ether $(18.8 \mathrm{~mL})$ under an argon atmosphere was cooled to $78{ }^{\circ} \mathrm{C}$; then a $1.65 \mathrm{M}$ solution of tert-butyl lithium $(2.40 \mathrm{~mL}, 3.96$ mmol, 1.05 equiv) in pentane was added dropwise over approximately five minutes and the reaction was stirred at $-78{ }^{\circ} \mathrm{C}$ for $45 \mathrm{~min}$. A suspension of aldehyde $\mathbf{1 0}$ (1.33 g, $4.15 \mathrm{mmol}, 1.10$ equiv) in THF ( $3.3 \mathrm{~mL})$ was added to the solution in one portion; the flask that had contained aldehyde $\mathbf{1 0}$ was washed with THF $(2 \mathrm{~mL})$ and the washing was also added. The reaction was stirred at $-78^{\circ} \mathrm{C}$ for 45 min before it was warmed to room temperature and stirred for an additional $1.5 \mathrm{~h}$, then quenched with saturated $\mathrm{NH}_{4} \mathrm{Cl}$ solution (ca. $15 \mathrm{~mL}$ ). The mixture was poured into water $(50 \mathrm{~mL})$ and extracted with ethyl acetate $(3 \times 50 \mathrm{~mL})$. The combined extracts were washed with water $(1 \times 50 \mathrm{~mL})$ and brine $(1 \times 50 \mathrm{~mL})$ and dried over $\mathrm{MgSO}_{4}$. The solvents were removed in vacuo and the residue (1.79 g) was dissolved in DMSO (35.3 $\mathrm{mL})$. To this solution was added IBX (2.11 g, $7.54 \mathrm{mmol}, 2.00$ equiv) in one portion. After stirring at room temperature for $2 \mathrm{~h}$ open to the air, water $(30 \mathrm{~mL})$ and ethyl acetate $(10 \mathrm{~mL})$ were added and the reaction was stirred for $10 \mathrm{~min}$ before it was filtered through a pad of Celite, rinsing the Celite with ethyl acetate. The layers were separated and the aqueous layer was basified to $\mathrm{pH} 10$ using solid $\mathrm{K}_{2} \mathrm{CO}_{3}$. The aqueous layer then was extracted with ethyl acetate $(3 \times 50 \mathrm{~mL})$ and the combined organic extracts were washed sequentially with water $(1 \times 50 \mathrm{~mL})$ and brine $(1 \times 50 \mathrm{~mL})$ before being dried over $\mathrm{MgSO}_{4}$. After removal of solvents in vacuo the residue was purified by MPLC eluting with 1:99 methanol/dichloromethane $(200 \mathrm{~mL})$ and 2:98 methanol/dichloromethane (1.4 L) affording $14(0.77 \mathrm{~g}, 44 \%)$ as a white solid: mp 116-118 ${ }^{\circ} \mathrm{C} ;{ }^{1} \mathrm{H}$ NMR (400 MHz, $\left.\mathrm{CDCl}_{3}\right) \delta 0.98(\mathrm{~d}, J=6.6 \mathrm{~Hz}, 6 \mathrm{H}), 2.26(\mathrm{~m}, 1 \mathrm{H}), 2.78(\mathrm{~d}, J=7.4 \mathrm{~Hz}, 2 \mathrm{H}), 3.18(\mathrm{~s}, 3 \mathrm{H})$, $3.82(\mathrm{~s}, 3 \mathrm{H}), 3.99$ (s, 3H), 4.83 (s, 2H), $5.22(\mathrm{~s}, 2 \mathrm{H}), 6.92(\mathrm{~d}, J=8.6 \mathrm{~Hz}, 2 \mathrm{H}), 7.10$ (d, $J=$ $4.8 \mathrm{~Hz}, 1 \mathrm{H}), 7.39$ (d, $J=8.6 \mathrm{~Hz}, 2 \mathrm{H}), 7.81(\mathrm{~s}, 1 \mathrm{H}), 8.17(\mathrm{~s}, 1 \mathrm{H}), 8.41$ (d, $J=4.8 \mathrm{~Hz}, 1 \mathrm{H})$; ${ }^{13} \mathrm{C}$ NMR $\left(100 \mathrm{MHz}, \mathrm{CDCl}_{3}\right) \delta 22.9,28.5,41.6,55.4,56.8,57.1,70.7,100.2,107.7$, 114.2, 120.7, 127.1, 129.4, 132.6, 140.1, 143.9, 147.9, 148.6, 149.0, 154.2, 156.5, 159.7, 
193.1; IR (KBr) v 3059, 2953, 2831, $1670 \mathrm{~cm}^{-1}$; HRMS (ESI) $\mathrm{m} / \mathrm{z}$ calcd for $\mathrm{C}_{26} \mathrm{H}_{31} \mathrm{~N}_{2} \mathrm{O}_{6}$ 467.2182 $(\mathrm{M}+\mathrm{H})^{+}$, found 467.2168.

\section{(3-Hydroxy-2-isobutylpyridin-4-yl)(5-methoxy-4-(4-methoxybenzyloxy)pyridin-2- yl)methanone (15)}

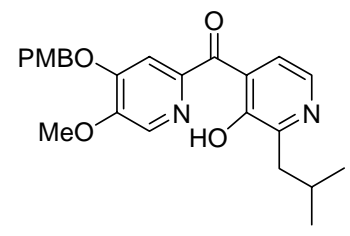

To a solution of 14 ( $0.237 \mathrm{~g}, 0.508 \mathrm{mmol}, 1.00$ equiv) in a mixture of DCM $(11.0 \mathrm{~mL})$ and ethanol $(11.0 \mathrm{~mL})$ was added conc. $\mathrm{HCl}$ $(0.5 \mathrm{~mL})$. The reaction was heated at $60{ }^{\circ} \mathrm{C}$, monitoring carefully by TLC (1:9 methanol/DCM). After $4 \mathrm{~h}$ the starting material had been consumed as judged by TLC so the reaction was poured into saturated $\mathrm{NaHCO}_{3}$ (30 $\mathrm{mL})$ and extracted with DCM $(4 \times 20 \mathrm{~mL})$. The combined extracts were washed with saturated $\mathrm{NaHCO}_{3}(1 \times 30 \mathrm{~mL})$ and brine $(1 \times 30 \mathrm{~mL})$ before being dried over $\mathrm{MgSO}_{4}$. After removal of solvents in vacuo, the residue was purified by preparative thin layer chromatography eluting with 1:9 methanol/DCM and extracting the compound off of the silica with 1:1 ethyl acetate/DCM to afford $15(0.119 \mathrm{~g}, 55 \%)$ as a bright yellow solid: mp 119-121 ${ }^{\circ} \mathrm{C} ;{ }^{1} \mathrm{H}$ NMR $\left(400 \mathrm{MHz}, \mathrm{CDCl}_{3}\right) \delta 0.98(\mathrm{~d}, J=6.6 \mathrm{~Hz}, 6 \mathrm{H}), 2.25(\mathrm{~m}, 1 \mathrm{H})$, $2.85(\mathrm{~d}, J=7.4 \mathrm{~Hz}, 2 \mathrm{H}), 3.82(\mathrm{~s}, 3 \mathrm{H}), 4.05(\mathrm{~s}, 3 \mathrm{H}), 5.24(\mathrm{~s}, 2 \mathrm{H}), 6.94(\mathrm{~d}, J=8.4 \mathrm{~Hz}, 2 \mathrm{H})$, $7.40(\mathrm{~d}, J=8.4 \mathrm{~Hz}, 2 \mathrm{H}), 7.81(\mathrm{~d}, J=5.3 \mathrm{~Hz}, 1 \mathrm{H}), 7.84(\mathrm{~s}, 1 \mathrm{H}), 8.12(\mathrm{~d}, J=5.3 \mathrm{~Hz}, 1 \mathrm{H})$, $8.20(\mathrm{~s}, 1 \mathrm{H}) ;{ }^{13} \mathrm{C}$ NMR $\left(100 \mathrm{MHz}, \mathrm{CDCl}_{3}\right) \delta$ 23.0, 28.2, 42.1, 55.5, 57.1, 71.1, 109.5, 114.4, 122.6, 126.2, 126.8, 129.6, 129.8, 138.3, 148.1, 149.2, 152.2, 155.2, 155.7, 160.0, 192.1; IR (KBr) v 3430, 2953, 2865, 2835, 1637, $1611 \mathrm{~cm}^{-1}$; HRMS (ESI) $\mathrm{m} / \mathrm{z}$ calcd for $\mathrm{C}_{24} \mathrm{H}_{27} \mathrm{~N}_{2} \mathrm{O}_{5} 423.1920(\mathrm{M}+\mathrm{H})^{+}$, found 423.1926 .

\section{2-Isobutyl-4-(5-methoxy-4-(4-methoxybenzyloxy)-2-pyridinoyl)pyridin-3-yl trifluoromethanesulfonate (16)}

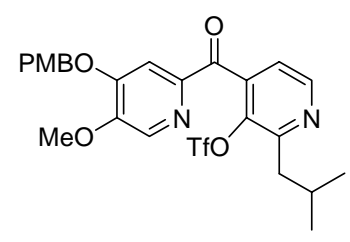

To a solution of 15 (40.5 $\mathrm{mg}, 0.0959 \mathrm{mmol}, 1.00$ equiv) in anhydrous DCM $(1.0 \mathrm{~mL})$ was added freshly distilled pyridine ( $0.02 \mathrm{~mL}, 0.3 \mathrm{mmol}, 3$ equiv) under an argon atmosphere and the solution was stirred for 15 min prior to the addition of triflic 
anhydride $(0.02 \mathrm{~mL}, 0.1 \mathrm{mmol}, 1$ equiv). After stirring at room temperature for $3 \mathrm{~h}$, the reaction was poured into water $(20 \mathrm{~mL})$ and extracted with ethyl acetate $(3 \times 15 \mathrm{~mL})$. The combined extracts were washed with water $(2 \times 30 \mathrm{~mL})$ and brine $(1 \times 30 \mathrm{~mL})$ before being dried over $\mathrm{MgSO}_{4}$. Removal of solvents in vacuo afforded 16 (60.8 mg, essentially quantitative) as a flaky yellow solid: mp $127-129{ }^{\circ} \mathrm{C} ;{ }^{1} \mathrm{H}$ NMR $\left(400 \mathrm{MHz}, \mathrm{CDCl}_{3}\right) \delta$ $1.00(\mathrm{~d}, J=6.5 \mathrm{~Hz}, 6 \mathrm{H}), 2.29$ (m, 1H), 2.86 (d, $J=7.3 \mathrm{~Hz}, 2 \mathrm{H}), 3.82(\mathrm{~s}, 3 \mathrm{H}), 4.01(\mathrm{~s}, 3 \mathrm{H})$, $5.22(\mathrm{~s}, 2 \mathrm{H}), 6.93(\mathrm{~d}, J=8.7 \mathrm{~Hz}, 2 \mathrm{H}), 7.39(\mathrm{~d}, J=4.8 \mathrm{~Hz}, 1 \mathrm{H}), 7.40(\mathrm{~d}, J=8.7 \mathrm{~Hz}, 2 \mathrm{H})$, $7.84(\mathrm{~s}, 1 \mathrm{H}), 8.14(\mathrm{~s}, 1 \mathrm{H}), 8.68(\mathrm{~d}, J=4.8 \mathrm{~Hz}, 1 \mathrm{H}) ;{ }^{13} \mathrm{C} \mathrm{NMR}\left(100 \mathrm{MHz}, \mathrm{CDCl}_{3}\right) \delta 22.7$, 28.6, 41.6, 55.5, 57.0, 70.9, 108.1, 114.3, 118.4 (q, $J=320.5 \mathrm{~Hz}, 1 \mathrm{C}), 122.5,127.1$, 129.6, 132.5, 140.4, 140.8, 146.8, 148.5, 149.2, 154.4, 155.8, 159.9, 190.1; IR (KBr) v $3076,2958,2865,2835,1683 \mathrm{~cm}^{-1}$; HRMS (ESI) $\mathrm{m} / \mathrm{z}$ calcd for $\mathrm{C}_{25} \mathrm{H}_{26} \mathrm{~N}_{2} \mathrm{O}_{7} \mathrm{SF}_{3} 555.1413$ $(\mathrm{M}+\mathrm{H})^{+}$, found 555.1412 .

\section{2-Isobutyl-4-(5-methoxy-4-oxo-1,4-dihydro-2-pyridinoyl)pyridin-3-yl trifluoromethanesulfonate (3)}

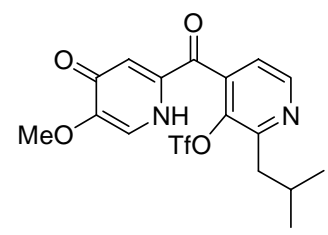

To a solution of trifluoroacetic acid $(0.3 \mathrm{~mL})$ in DCM $(2.7 \mathrm{~mL})$ under an argon atmosphere was added 16 (32.1 mg, $0.0579 \mathrm{mmol}$, 1.00 equiv). After stirring at room temperature for $1 \mathrm{~h}$, the reaction was poured into saturated sodium bicarbonate solution $(30 \mathrm{~mL})$ and extracted with DCM (3 x $15 \mathrm{~mL})$. The combined extracts were washed with saturated $\mathrm{NaHCO}_{3}(1 \times 20 \mathrm{~mL})$ and brine $(1 \times 20 \mathrm{~mL})$, then dried over $\mathrm{MgSO}_{4}$. After removal of solvents in vacuo the residue was purified by preparative thin layer chromatography eluting with 1:9 methanol/dichloromethane and extracting the compound off of the silica with 1:1 methanol/DCM to yield 3 (14.3 $\mathrm{mg}, 57 \%)$ as a light yellow solid: $\mathrm{mp} 99-100{ }^{\circ} \mathrm{C}$ (decomp); ${ }^{1} \mathrm{H}$ NMR (400 MHz, $\left.\mathrm{CDCl}_{3}\right) \delta 0.98$ (d, J=6.5 Hz, 6H), $2.74(\mathrm{~m}, 1 \mathrm{H}), 2.85$ (d, $J=7.4 \mathrm{~Hz}, 2 \mathrm{H}), 4.00$ (s, 3H), 7.37 (d, J = 4.8 Hz, 1H), 7.68 (b, 1H), 8.06 (b, 1H), 8.65 (d, $J=4.8 \mathrm{~Hz}, 1 \mathrm{H}$ ); compound 3 decomposes over time so it was not possible to obtain a good ${ }^{13} \mathrm{C}$ NMR spectrum; IR (KBr) v 3418, 3067, 2958, 2873, 2852, $1679 \mathrm{~cm}^{-1}$; HRMS (ESI) $\mathrm{m} / \mathrm{z}$ calcd for $\mathrm{C}_{17} \mathrm{H}_{18} \mathrm{~N}_{2} \mathrm{O}_{6} \mathrm{SF}_{3} 435.0838(\mathrm{M}+\mathrm{H})^{+}$, found 435.0821 . 


\section{Pterocellin A (1)}

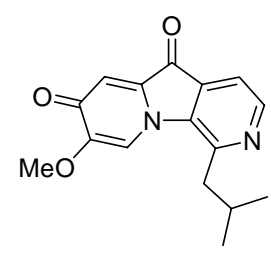

This reaction was done in two batches, each with equal amounts of $\mathbf{3}$ (13.6 $\mathrm{mg}$ each) and the two were combined in the end for purification and recrystallization. To a solution of $3(13.6 \mathrm{mg}, 0.0313 \mathrm{mmol}, 1.00$ equiv) in DMF $(0.7 \mathrm{~mL})$ under an argon atmosphere was added 18crown-6 (1.7 mg, $0.006 \mathrm{mmol}, 0.2$ equiv) and anhydrous $\mathrm{K}_{2} \mathrm{CO}_{3}(13.0 \mathrm{mg}, 0.0939 \mathrm{mmol}$, 3.00 equiv). The solution was heated overnight at $50{ }^{\circ} \mathrm{C}$. The reaction was then cooled to room temperature, poured into water $(20 \mathrm{~mL})$ and extracted with ethyl acetate $(4 \times 15$ $\mathrm{mL})$. The combined extracts were washed with brine $(1 \times 30 \mathrm{~mL})$ before being dried over $\mathrm{MgSO}_{4}$. Removal of solvents in vacuo yielded $1(5.0 \mathrm{mg}$ and $6.0 \mathrm{mg}$ for the first and second batches respectively, a combined yield of $11.0 \mathrm{mg}$ ) as a dark red solid. Analytically pure material was obtained by preparative thin layer chromatography eluting with ethyl acetate twice and extracting the compound off of the silica with 1:4 ethyl acetate/methanol to yield $10.2 \mathrm{mg}(57 \%)$ of 1 . Recrystallization from toluene afforded tiny red needle-like crystals: mp $179-181{ }^{\circ} \mathrm{C}$, lit. ${ }^{6} 172-173{ }^{\circ} \mathrm{C}$; UV-vis $(\mathrm{MeOH}) \lambda_{\max }(\log$ ع) 201 (3.99), 256 (3.83), 280 (4.06), 486 (3.07); ${ }^{1} \mathrm{H}$ NMR (400 MHz, $\left.\mathrm{CDCl}_{3}\right) \delta 1.11$ (d, J $=6.6 \mathrm{~Hz}, 6 \mathrm{H}), 2.25(\mathrm{~m}, 1 \mathrm{H}), 3.12(\mathrm{~d}, J=7.2 \mathrm{~Hz}, 2 \mathrm{H}), 3.95(\mathrm{~s}, 3 \mathrm{H}), 7.10(\mathrm{~s}, 1 \mathrm{H}), 7.55(\mathrm{~d}$, $J=4.7 \mathrm{~Hz}, 1 \mathrm{H}), 7.81(\mathrm{~s}, 1 \mathrm{H}), 8.62(\mathrm{~d}, J=4.7 \mathrm{~Hz}, 1 \mathrm{H}) ;{ }^{13} \mathrm{C} \mathrm{NMR}\left(100 \mathrm{MHz}, \mathrm{CDCl}_{3}\right) \delta$ $22.8,28.9,45.1,56.9,115.0,115.4,116.2$, 130.2, 136.0, 140.6, 146.8, 147.3, 151.7, 173.0, 184.3; IR (KBr) v 3080; 2958, 2869, 1729, 1637, $1599 \mathrm{~cm}^{-1}$; HRMS (ESI) $\mathrm{m} / \mathrm{z}$ calcd for $\mathrm{C}_{16} \mathrm{H}_{17} \mathrm{~N}_{2} \mathrm{O}_{3} 285.1239(\mathrm{M}+\mathrm{H})^{+}$, found 285.1228 .

Synthetic and natural 1 were shown to be identical by TLC co-spotting using two solvent systems (1:9 methanol/DCM; ethyl acetate), ${ }^{1} \mathrm{H}$ NMR spiking experiments (included) and mixture melting point determination (see next page).

6. Yao, B.; Prinsep, M. R.; Nicholson, B.K.; Gordon, D. P. J. Nat. Prod. 2003, 66, 1074-1077. 


\section{Mixture Melting Point Comparison of Synthetic and Natural 1}

Synthetic 1: $\operatorname{mp} 179-183^{\circ} \mathrm{C}$

Natural 1: $\operatorname{mp} 177-181^{\circ} \mathrm{C}$

Mixture 1: $\operatorname{mp} 177-181^{\circ} \mathrm{C}$

The comparisons were performed using a Fisher Johns (cover glass) melting point apparatus rather than by using the standard melting point capillary method because of the very limited quantities of material available. Shortage of material compounded by the dark red color of the crystals (which made it difficult to see exactly when they melted) account for the somewhat broader melting point ranges compared to the $179-181{ }^{\circ} \mathrm{C}$ range obtained using a melting point capillary. 
Table 1. ${ }^{1} \mathrm{H}$ and ${ }^{13} \mathrm{C}$ NMR Data for the Natural Product ${ }^{6}$ and Synthetic $\mathbf{1}$

\begin{tabular}{|c|c|c|c|c|c|}
\hline \multicolumn{2}{|c|}{${ }^{1} \mathrm{H}$ NMR } & \multicolumn{2}{|c|}{${ }^{13} \mathrm{C}$ NMR } & \multicolumn{2}{|c|}{ UV - Vis } \\
\hline Natural 1 & Synthetic 1 & Natural 1 & Synthetic 1 & Natural 1 & Synthetic 1 \\
\hline $1.10(\mathrm{~d}, 6.6)^{*}$ & $1.11(\mathrm{~d}, 6.6)$ & 22.4 & 22.8 & $202(3.83)^{* *}$ & 201 (3.99) \\
\hline $2.25(\mathrm{~m})$ & $2.25(\mathrm{~m})$ & 28.5 & 28.9 & $256(3.70)$ & $256(3.83)$ \\
\hline $3.11(\mathrm{~d}, 7.3)$ & $3.12(\mathrm{~d}, 7.2)$ & 44.7 & 45.1 & $280(3.87)$ & $280(4.06)$ \\
\hline $3.94(\mathrm{~s})$ & $3.95(\mathrm{~s})$ & 56.6 & 56.9 & $483(2.93)$ & $486(3.07)$ \\
\hline $7.07(\mathrm{~s})$ & $7.10(\mathrm{~s})$ & 114.8 & 115.0 & & \\
\hline $7.53(\mathrm{~d}, 4.6)$ & $7.55(\mathrm{~d}, 4.7)$ & 115.3 & 115.4 & & \\
\hline $7.81(\mathrm{~s})$ & $7.81(\mathrm{~s})$ & 116.1 & 116.2 & & \\
\hline \multirow[t]{8}{*}{$8.61(\mathrm{~d}, 4.6)$} & $8.62(\mathrm{~d}, 4.7)$ & 130.3 & 130.4 & & \\
\hline & & 135.9 & 136.0 & & \\
\hline & & 140.5 & 140.6 & & \\
\hline & & 146.7 & 146.8 & & \\
\hline & & 147.3 & 147.3 & & \\
\hline & & 151.6 & 151.7 & & \\
\hline & & 173.0 & 173.0 & & \\
\hline & & 184.3 & 184.3 & & \\
\hline
\end{tabular}

$* \delta$ chemical shift in ppm (coupling pattern, coupling constant in $\mathrm{Hz}$ )

$* * \lambda_{\max }(\log \varepsilon)$ 

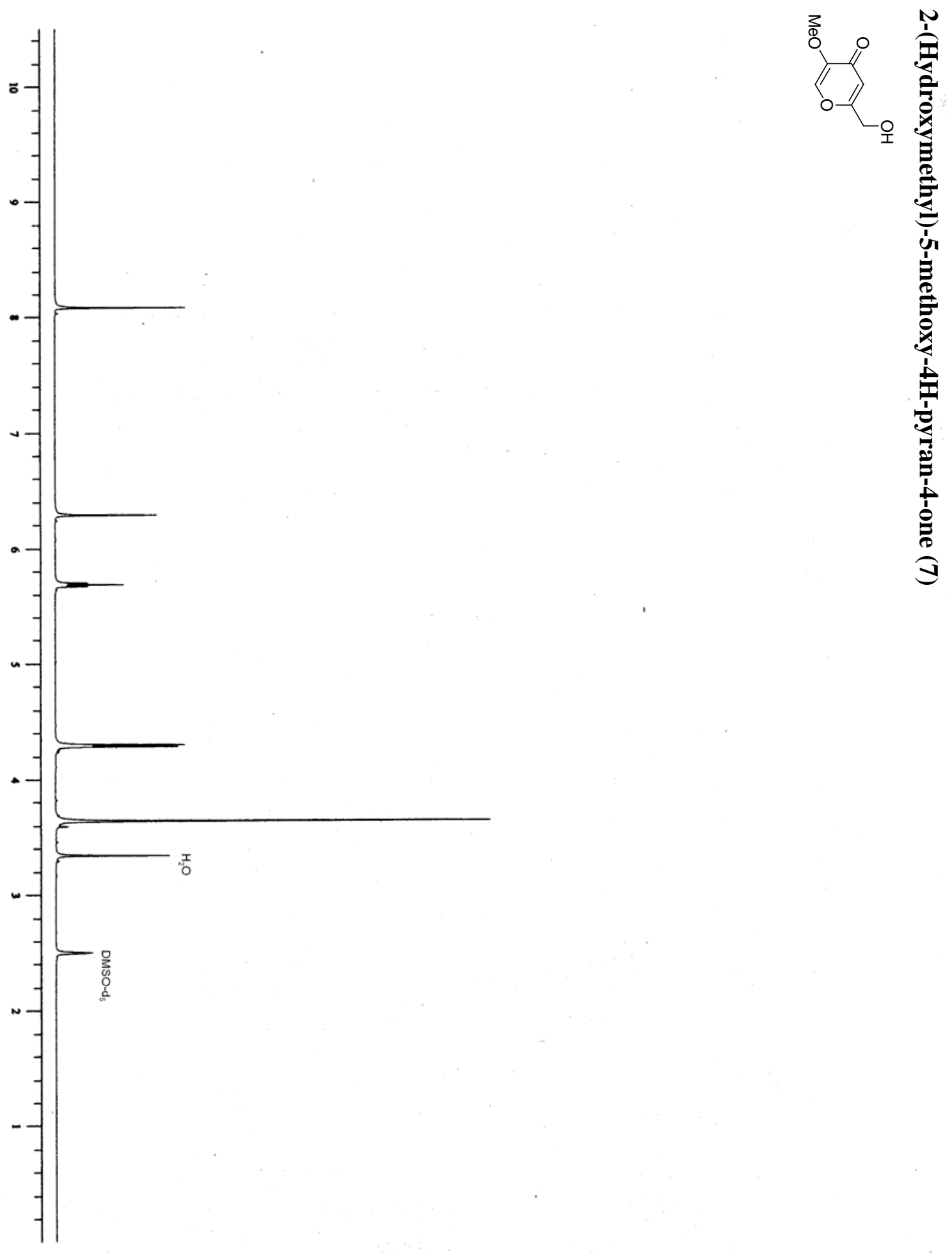

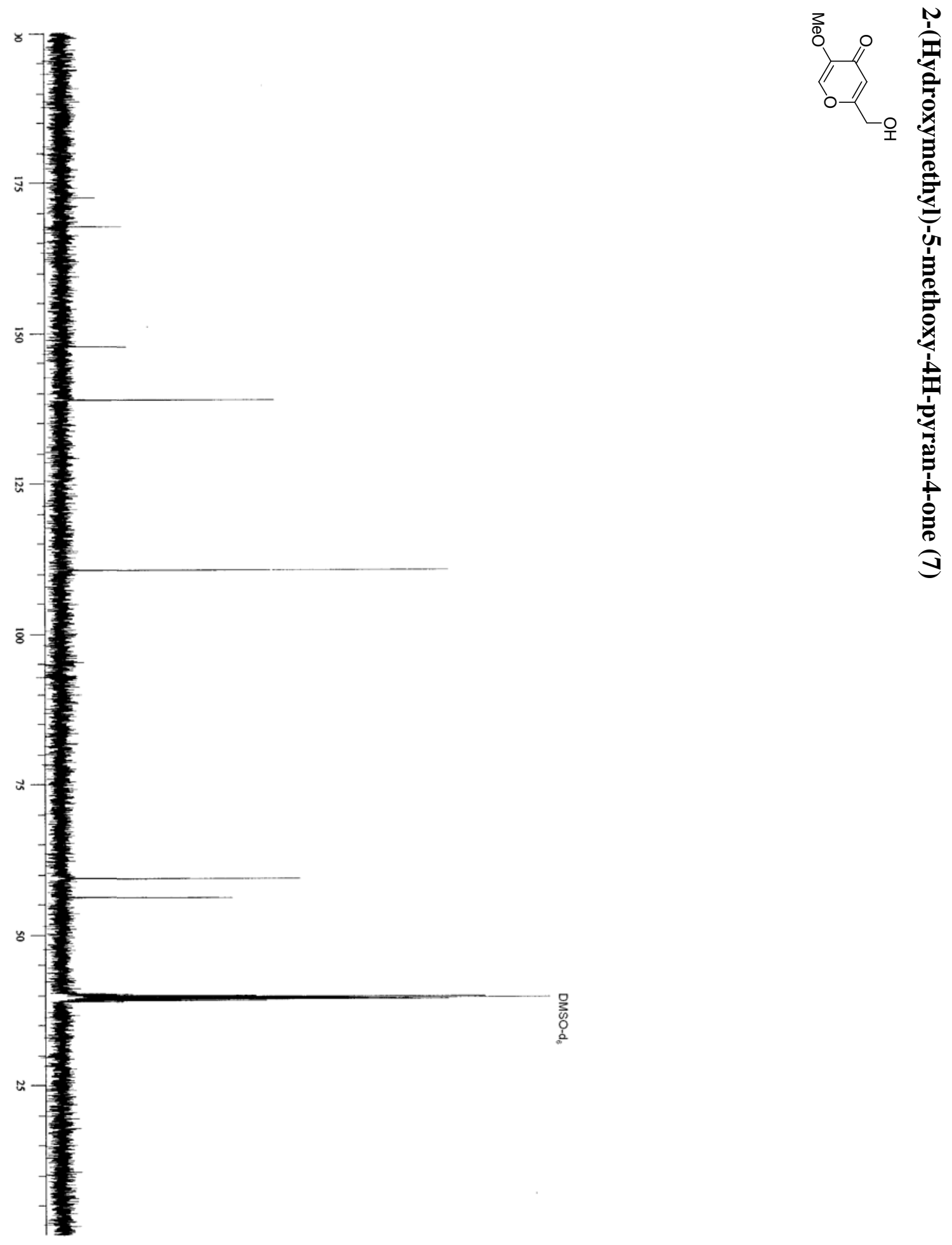

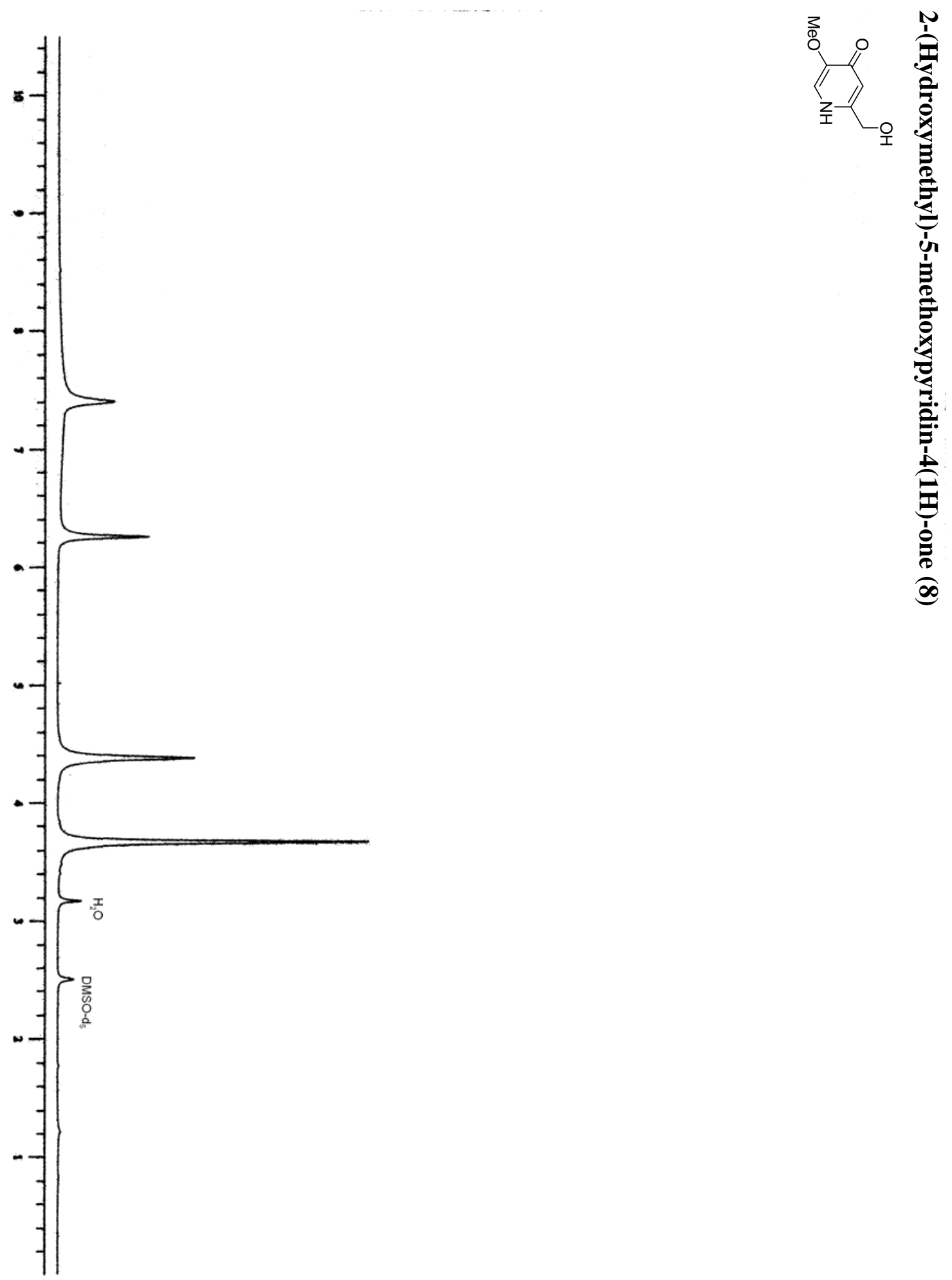


$$
z^{\prime \prime}
$$



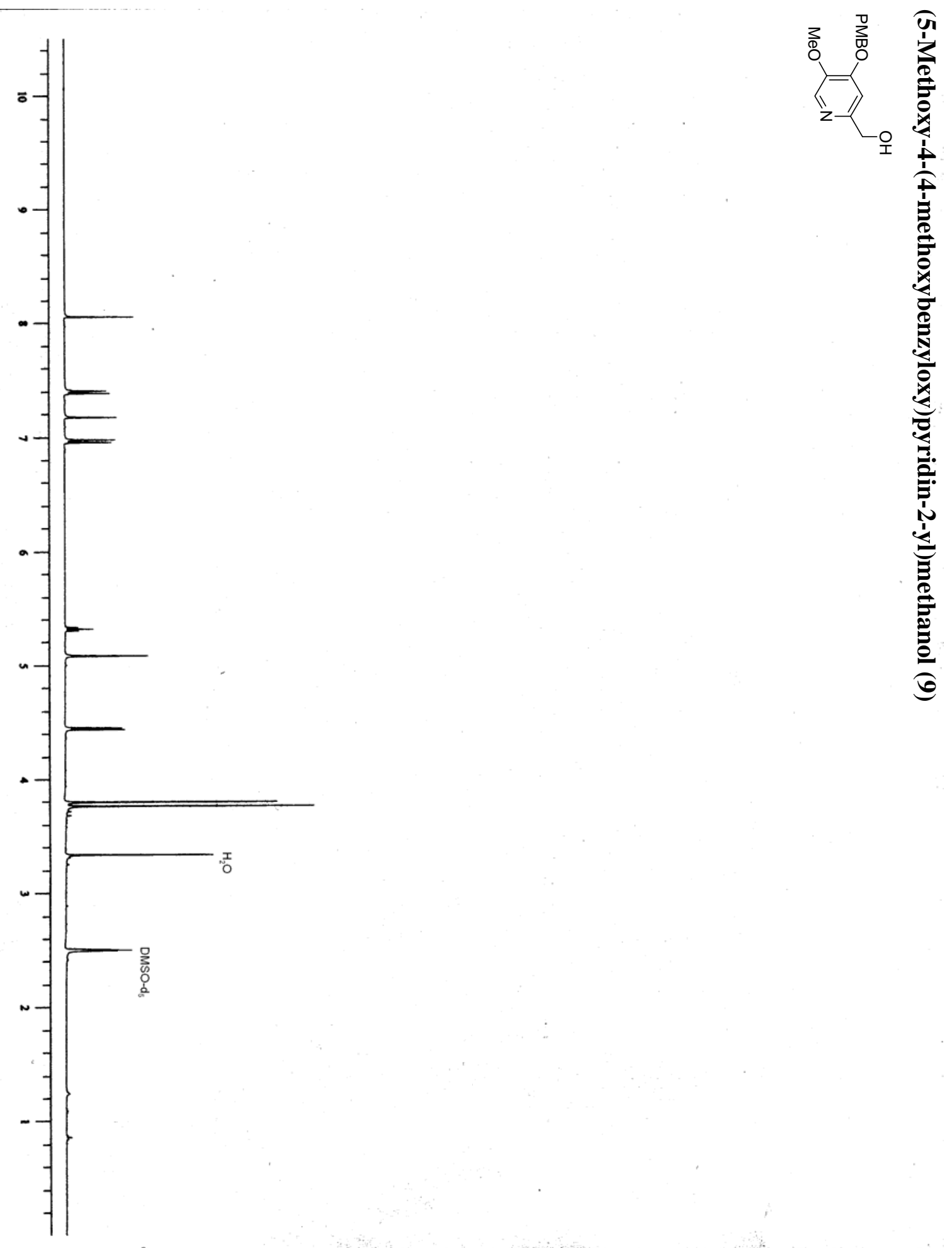

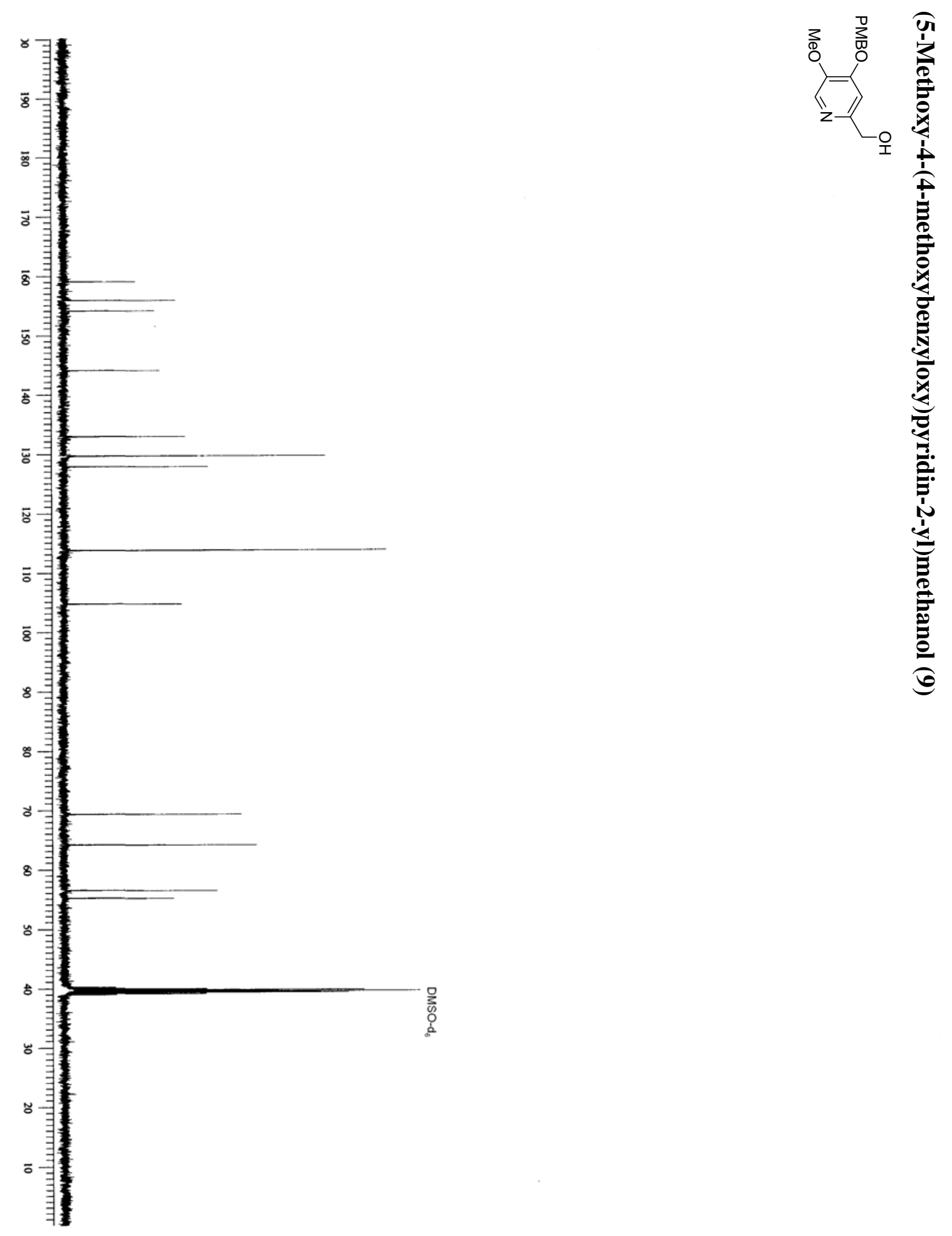

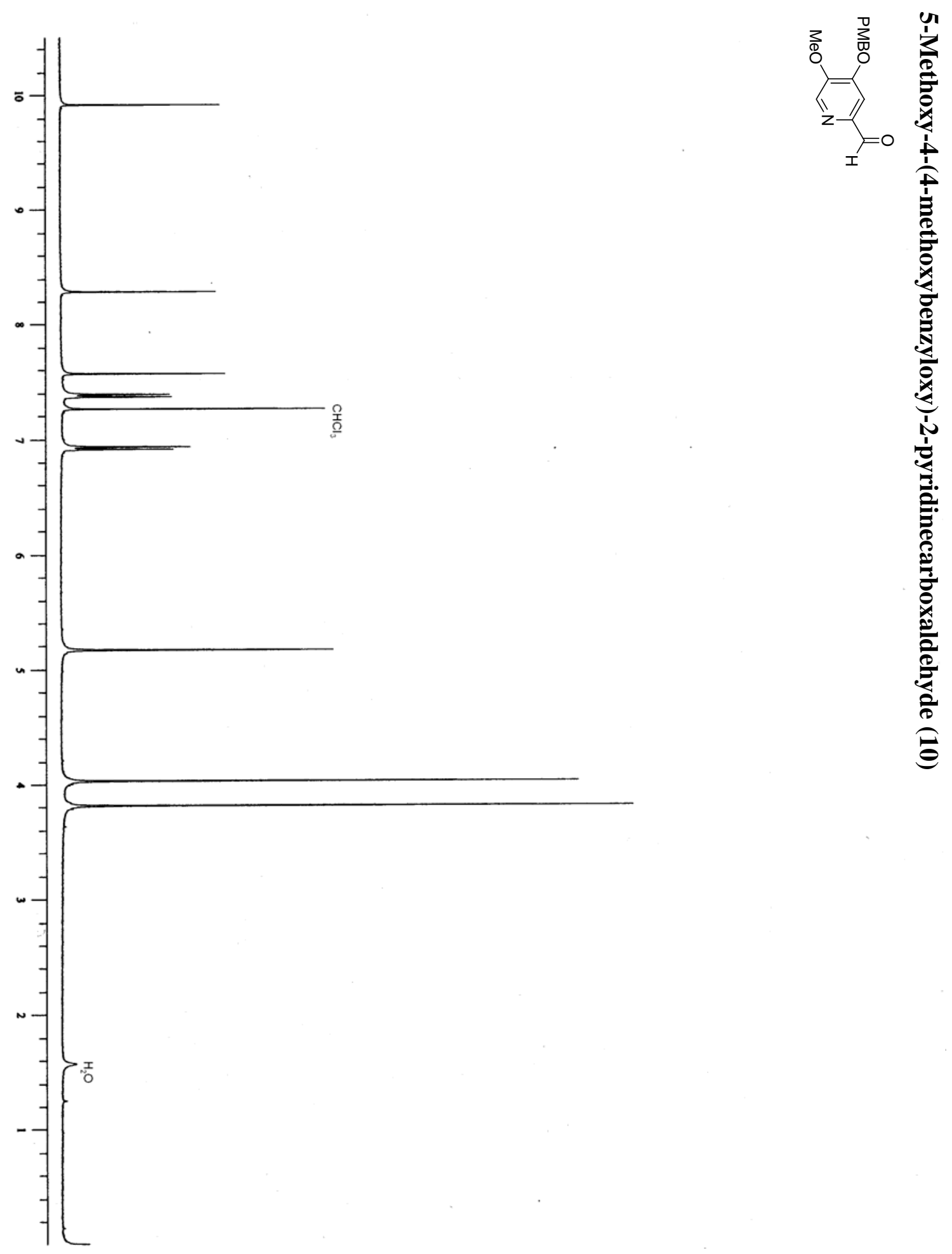

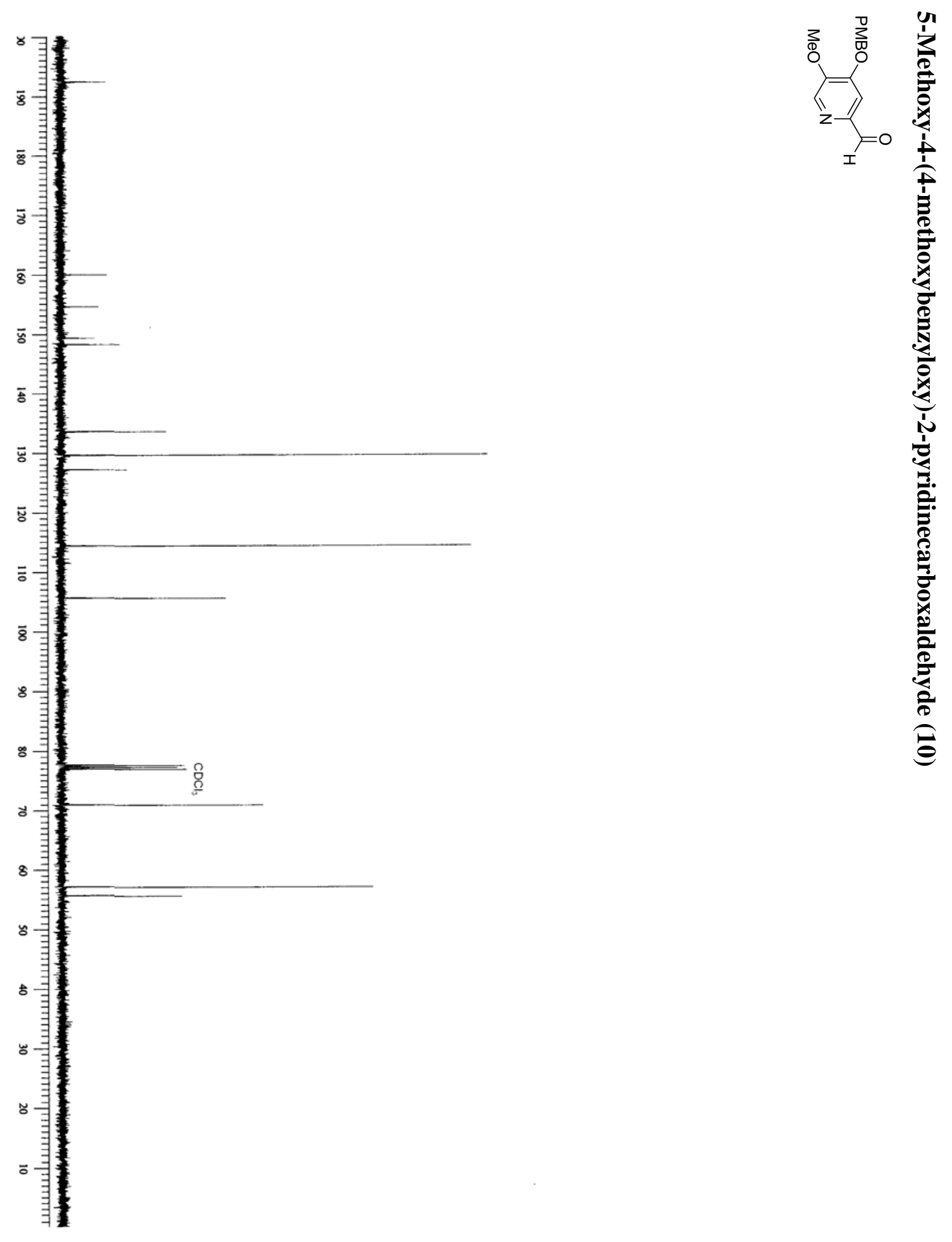


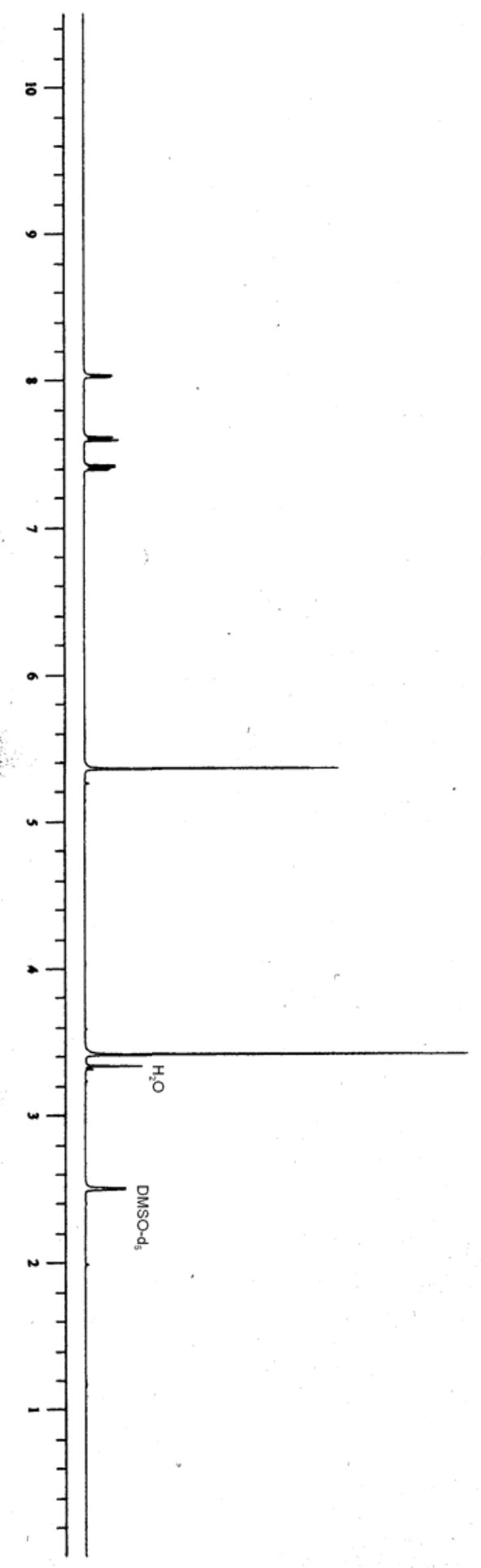

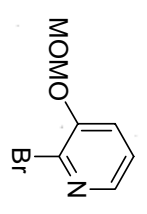

\begin{tabular}{l} 
N \\
$\mathbb{1}$ \\
0 \\
0 \\
0 \\
0 \\
0 \\
1 \\
1 \\
\hline 1
\end{tabular} 官

ํํำ

콩

$\stackrel{2}{2}$ 这 ్․․

클. 点 

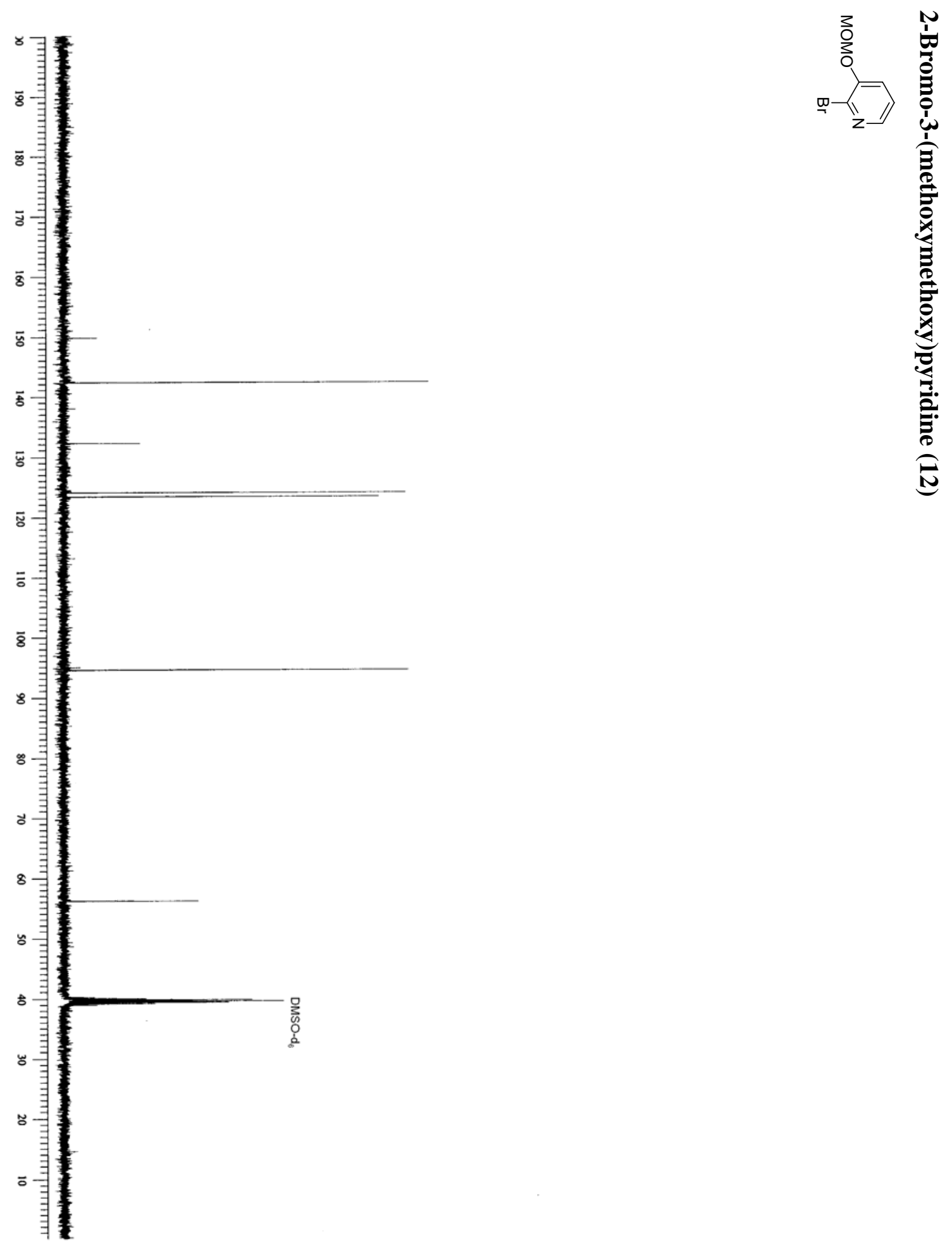

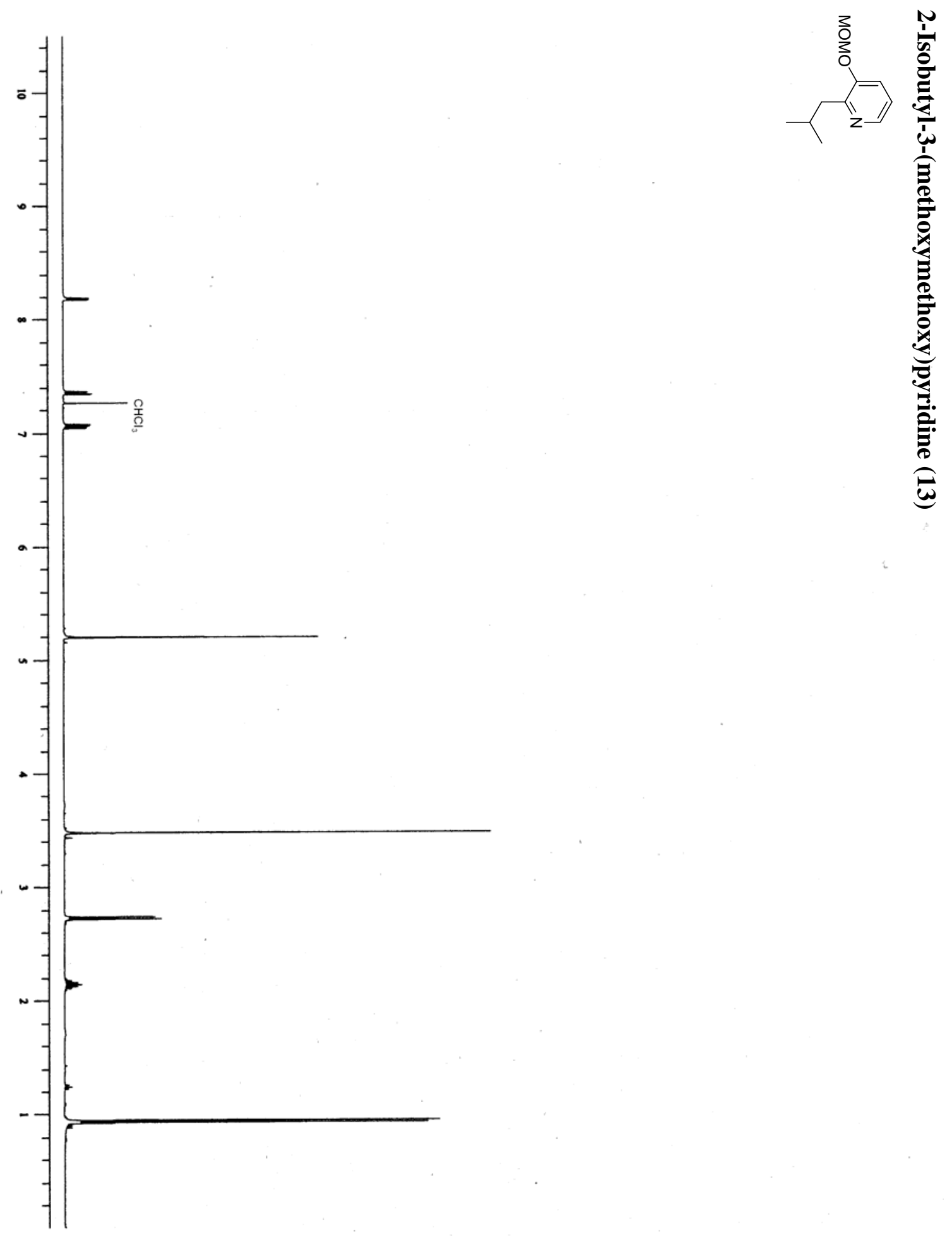

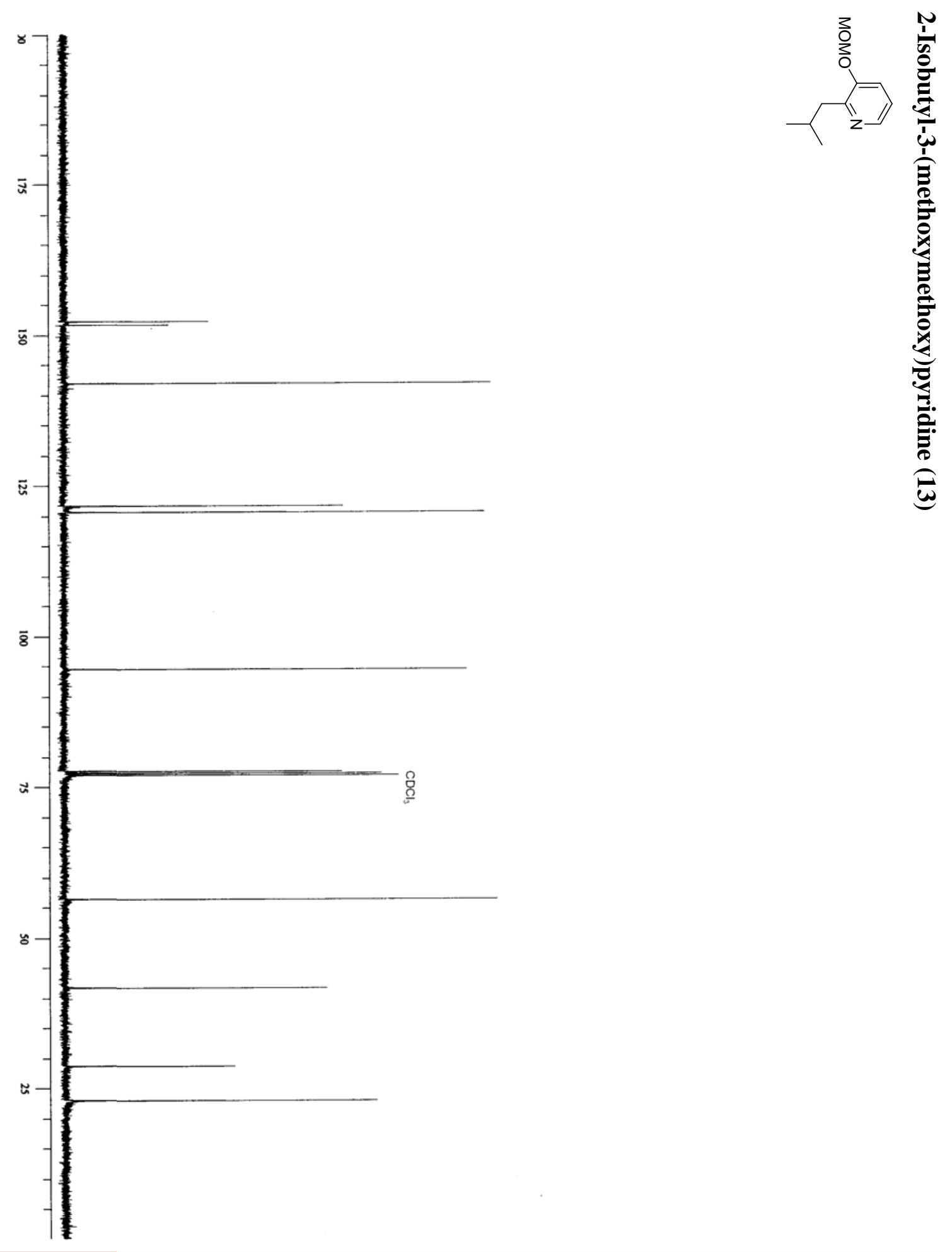

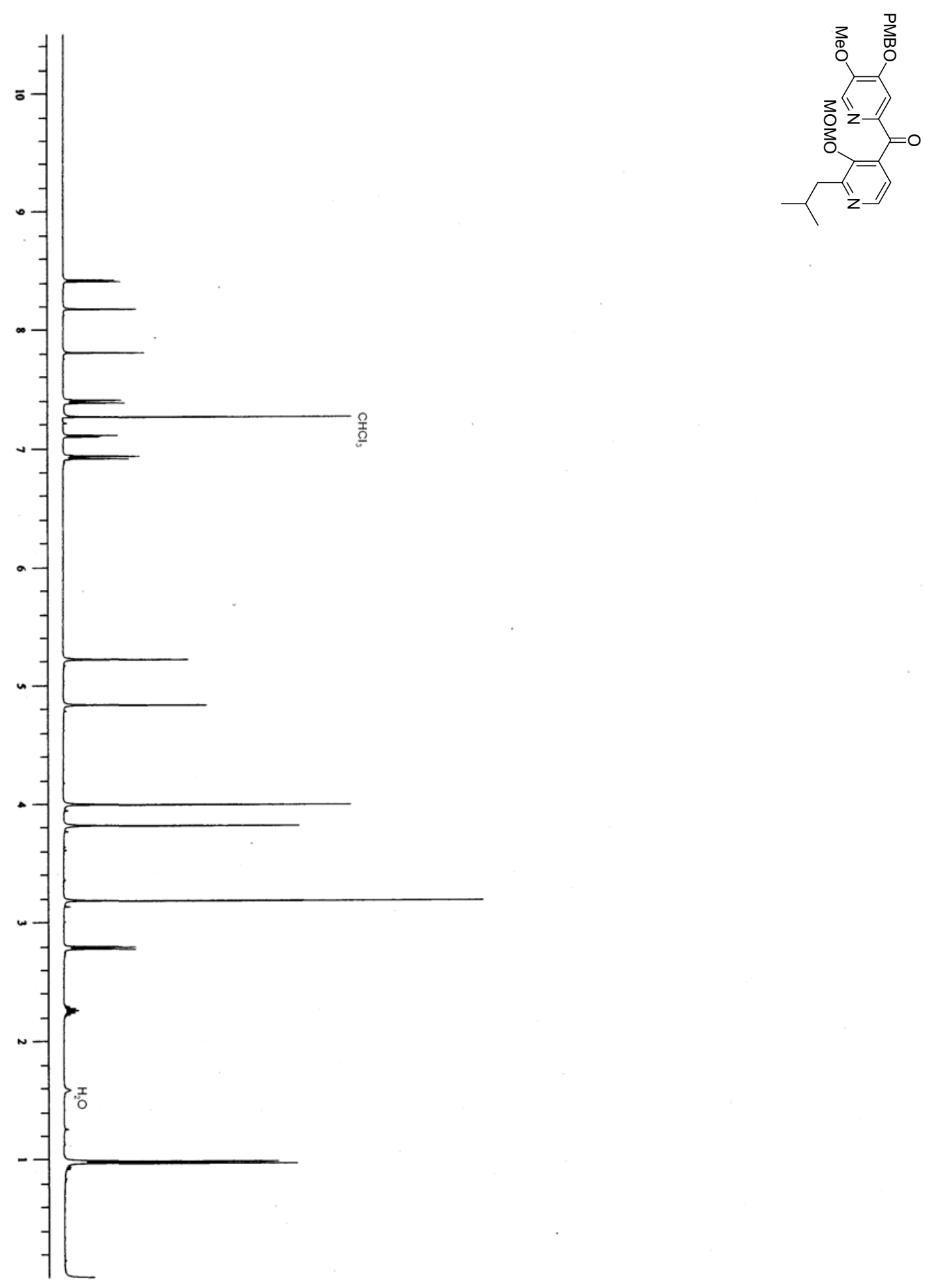

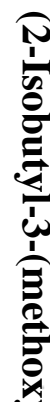

急

。

运

$\exists$

을

$\stackrel{+}{\dot{1}}$

ডิ

응

1

I

总

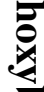

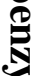

o

‥

N

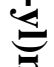

$\stackrel{8}{2}$

을

岦 

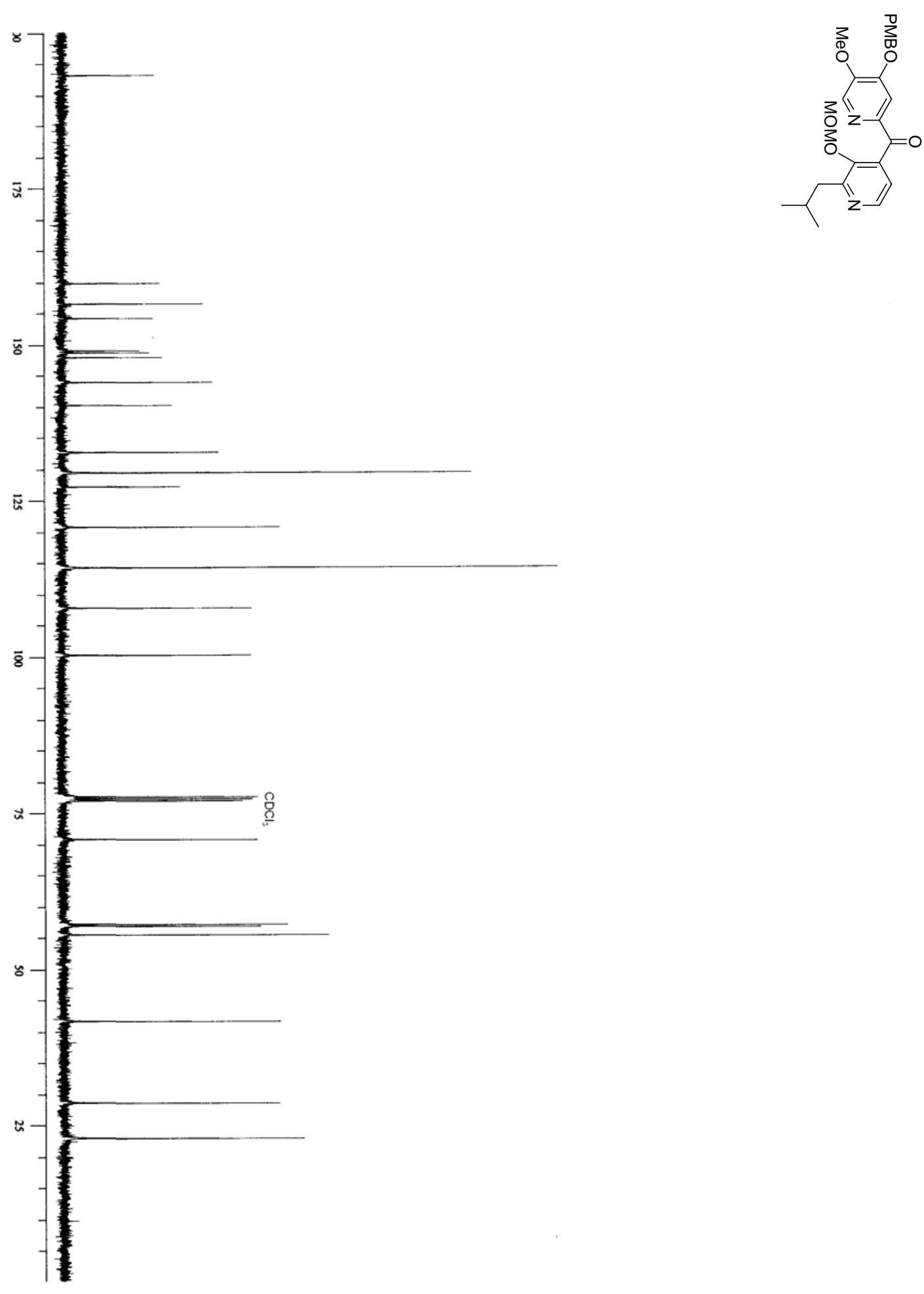

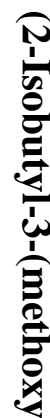

욜

这

$\leq$

ํ.

$\stackrel{+1}{\leftrightarrows}$

官

或

I

$\stackrel{+}{\stackrel{8}{E}}$

可

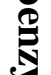

$\frac{1}{8}$

ত্가

축

N

昜 

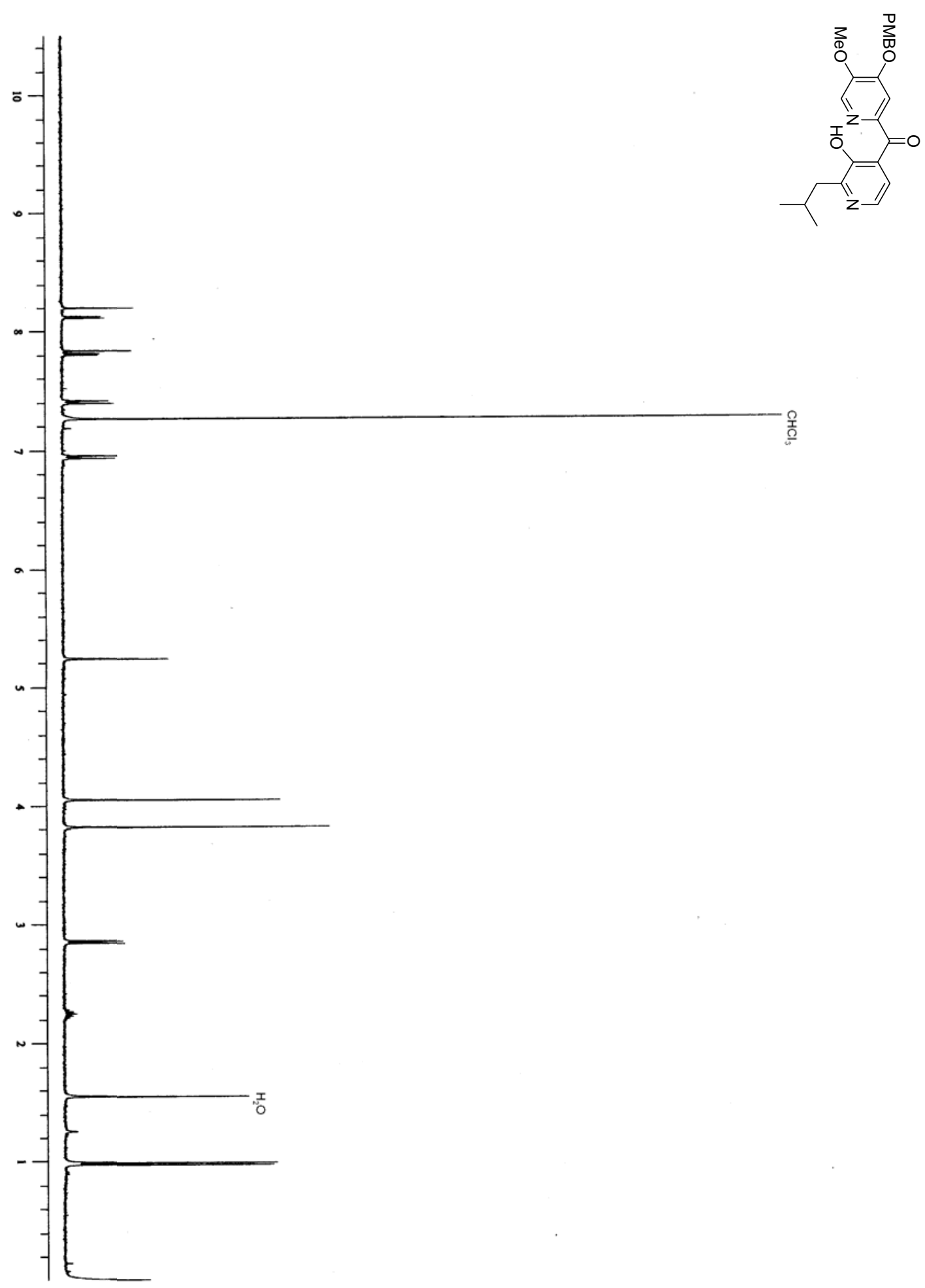

Uิ

‥

$\stackrel{1}{1}$

जิ



产

i

常

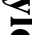



‥

ஸ்

苂 

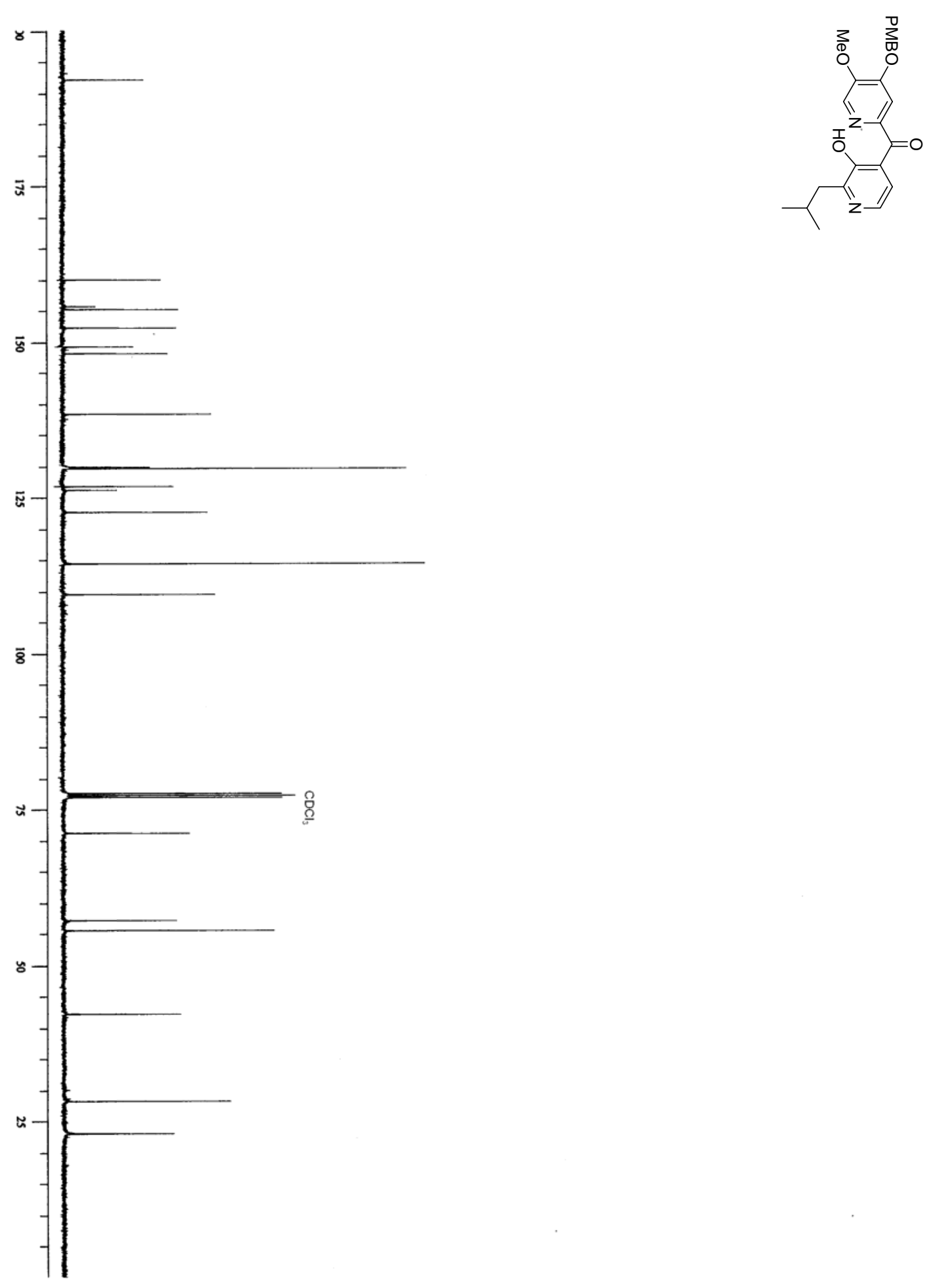

Ỡ

जิ

롤

気

$\stackrel{i}{+}$

兽

ํㅗㄹ

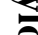

这

క

ํ. '

官 

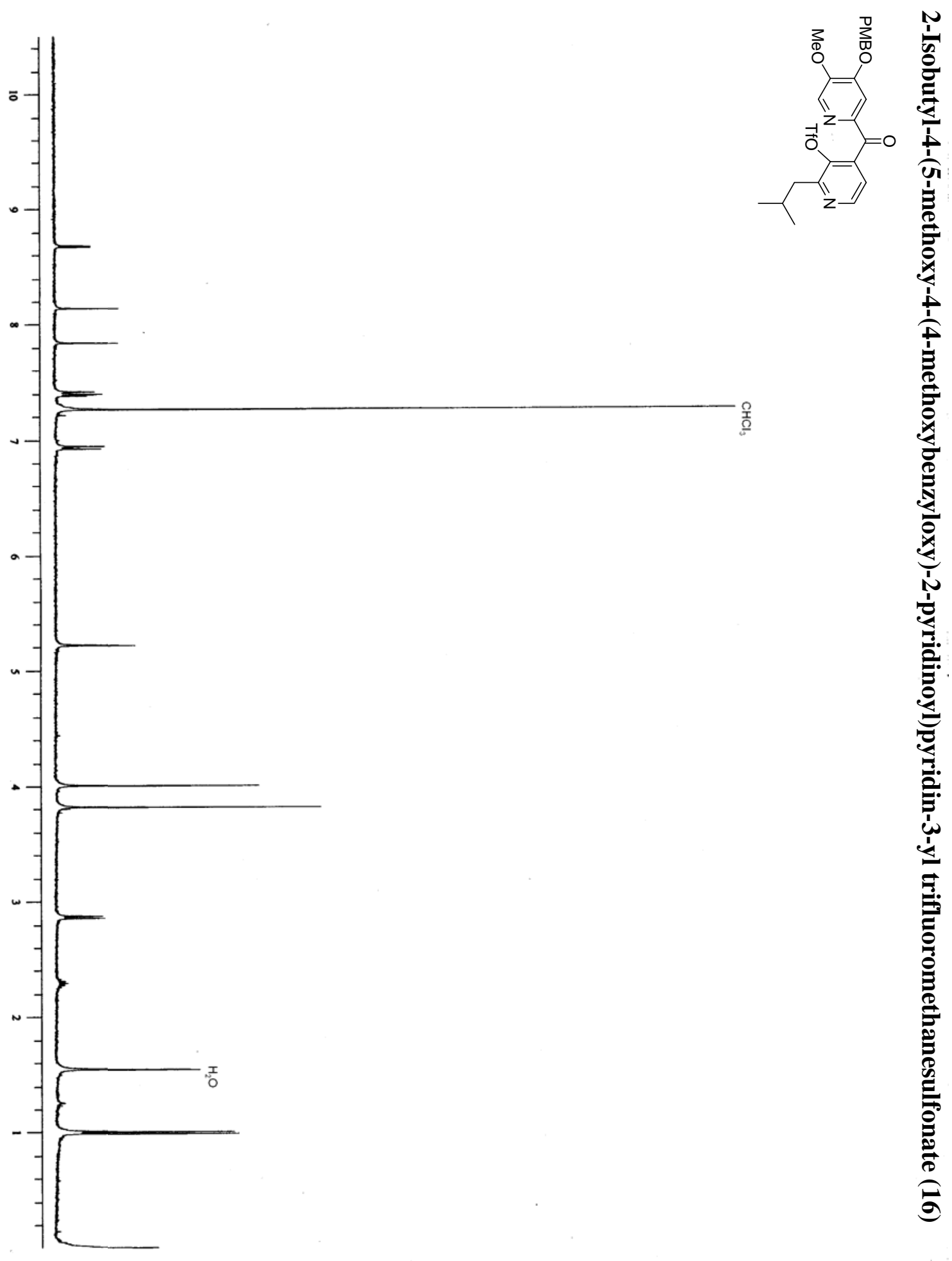

I

$\stackrel{2}{2}$

ช

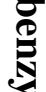

菼

'⿺辶

ㄱ.

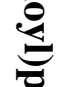

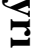

ํ.

w

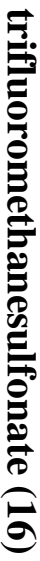



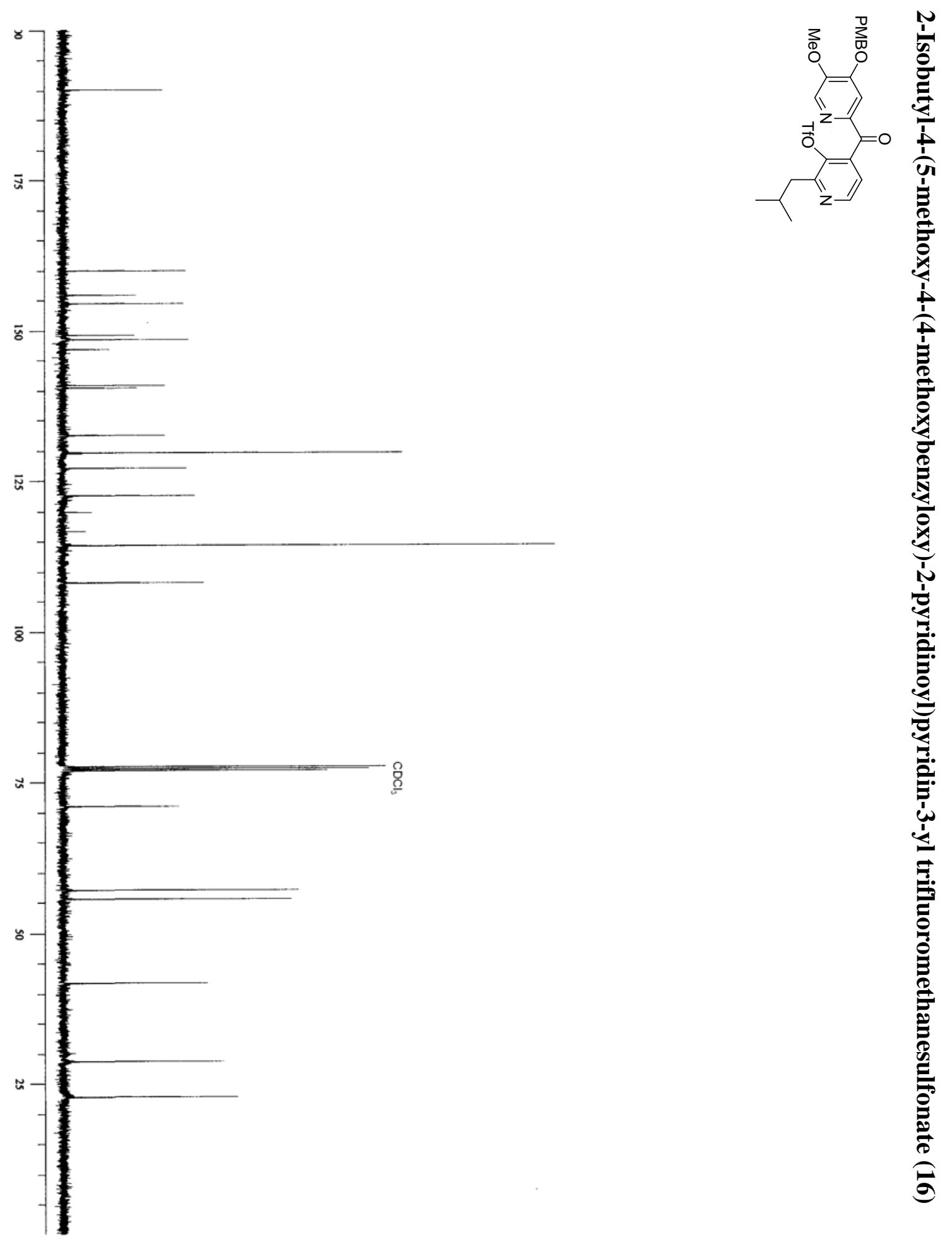

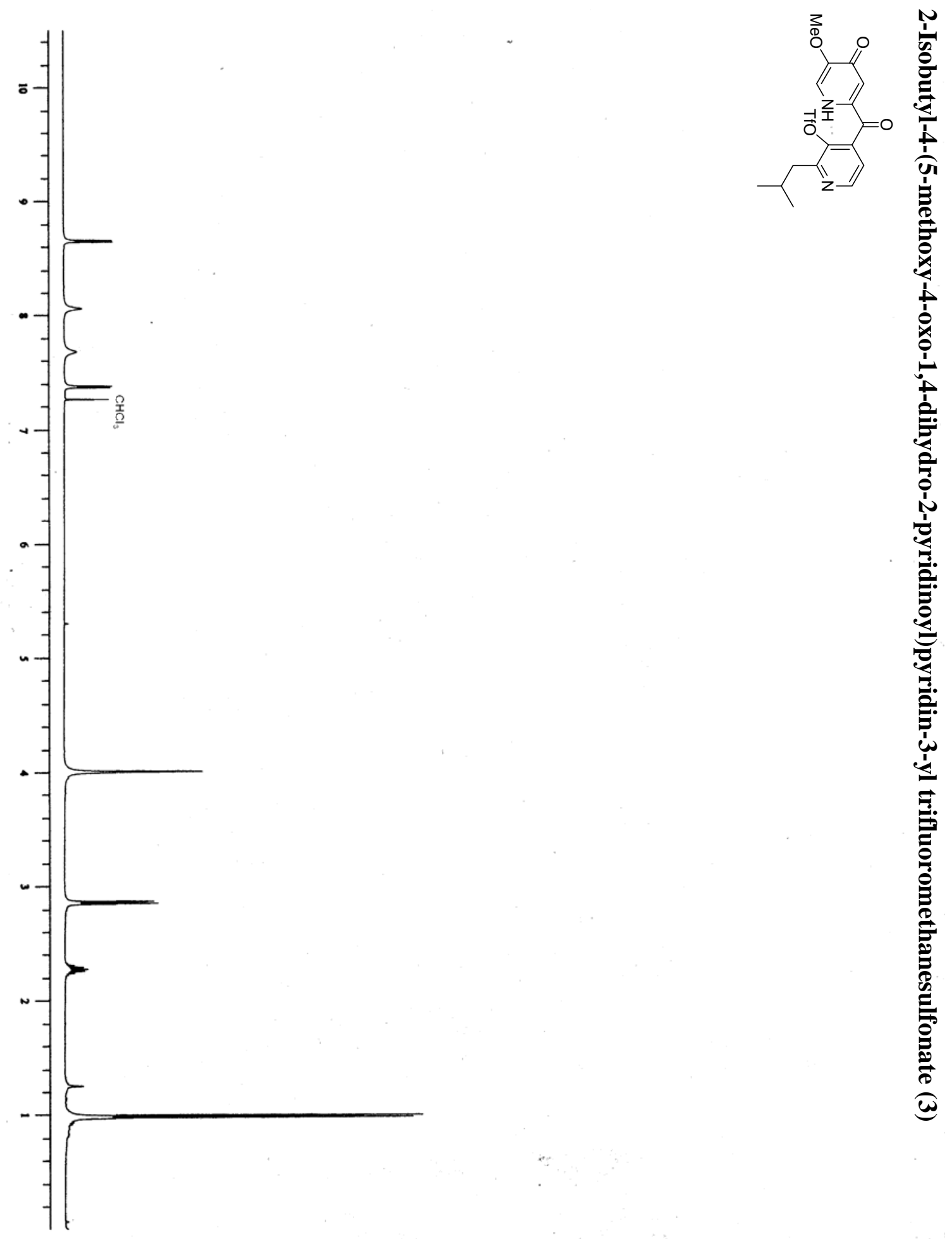

过

ì.

บِ

…ㄹ.

:

E.

흠

ڤ్ర 

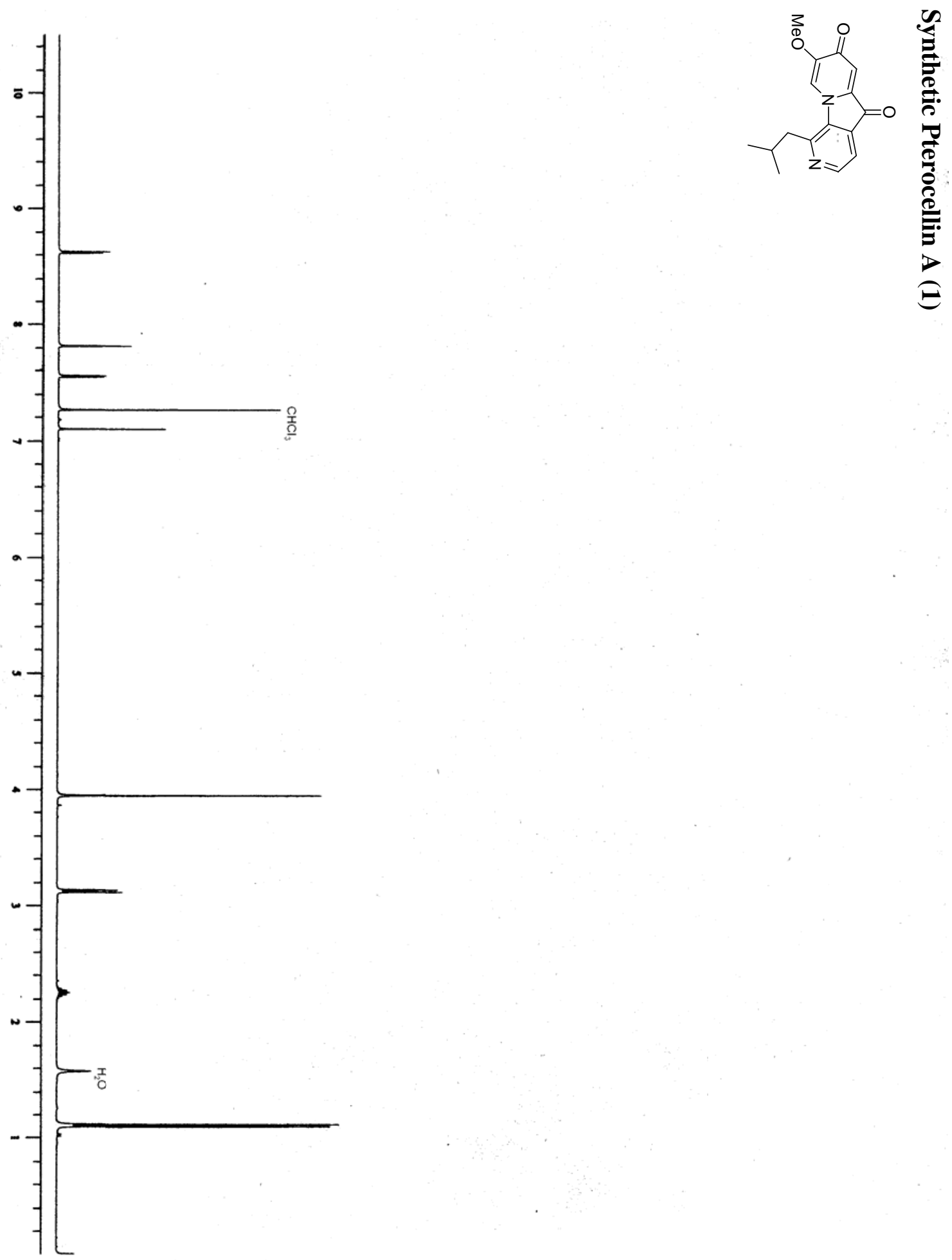

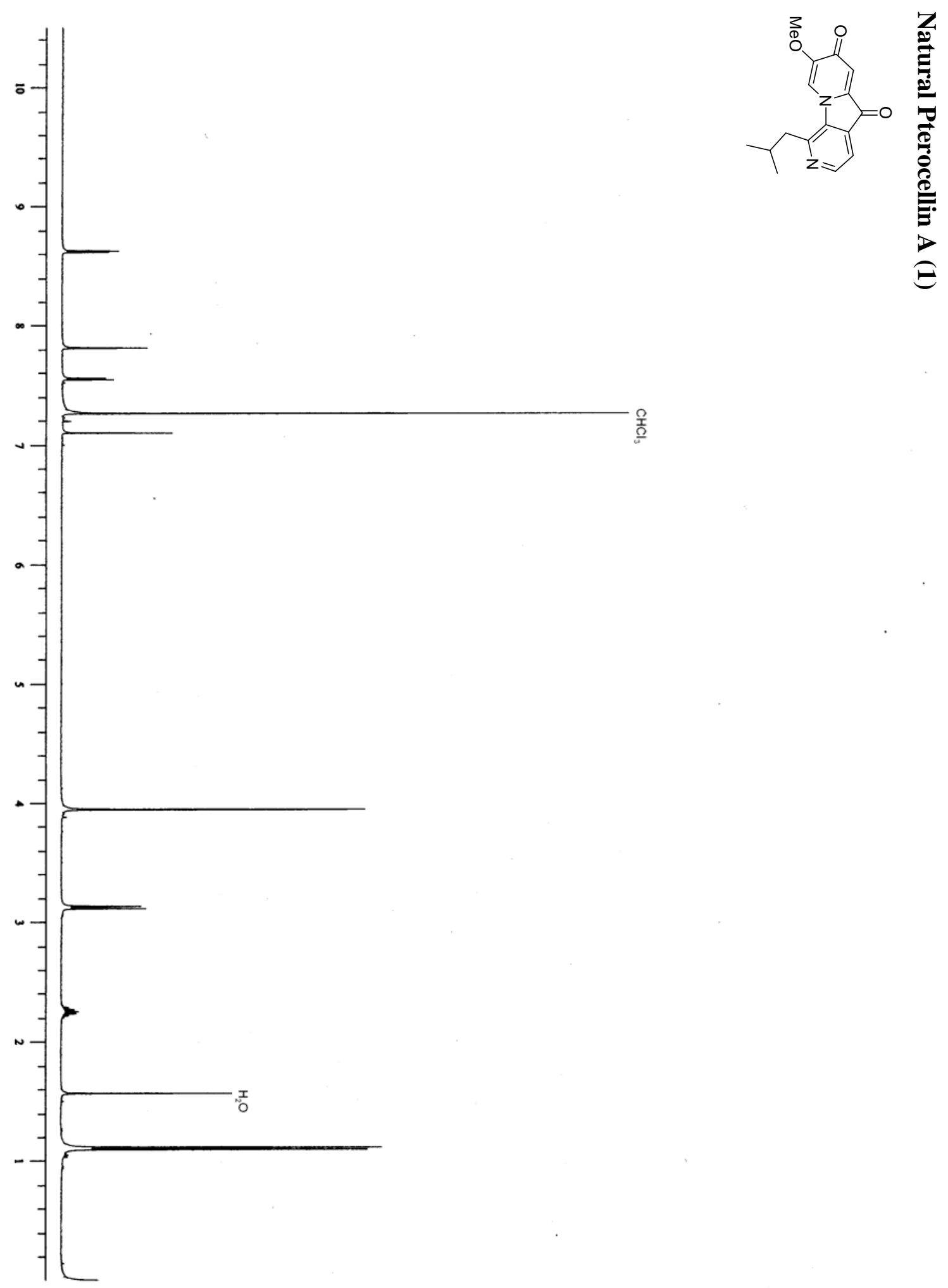

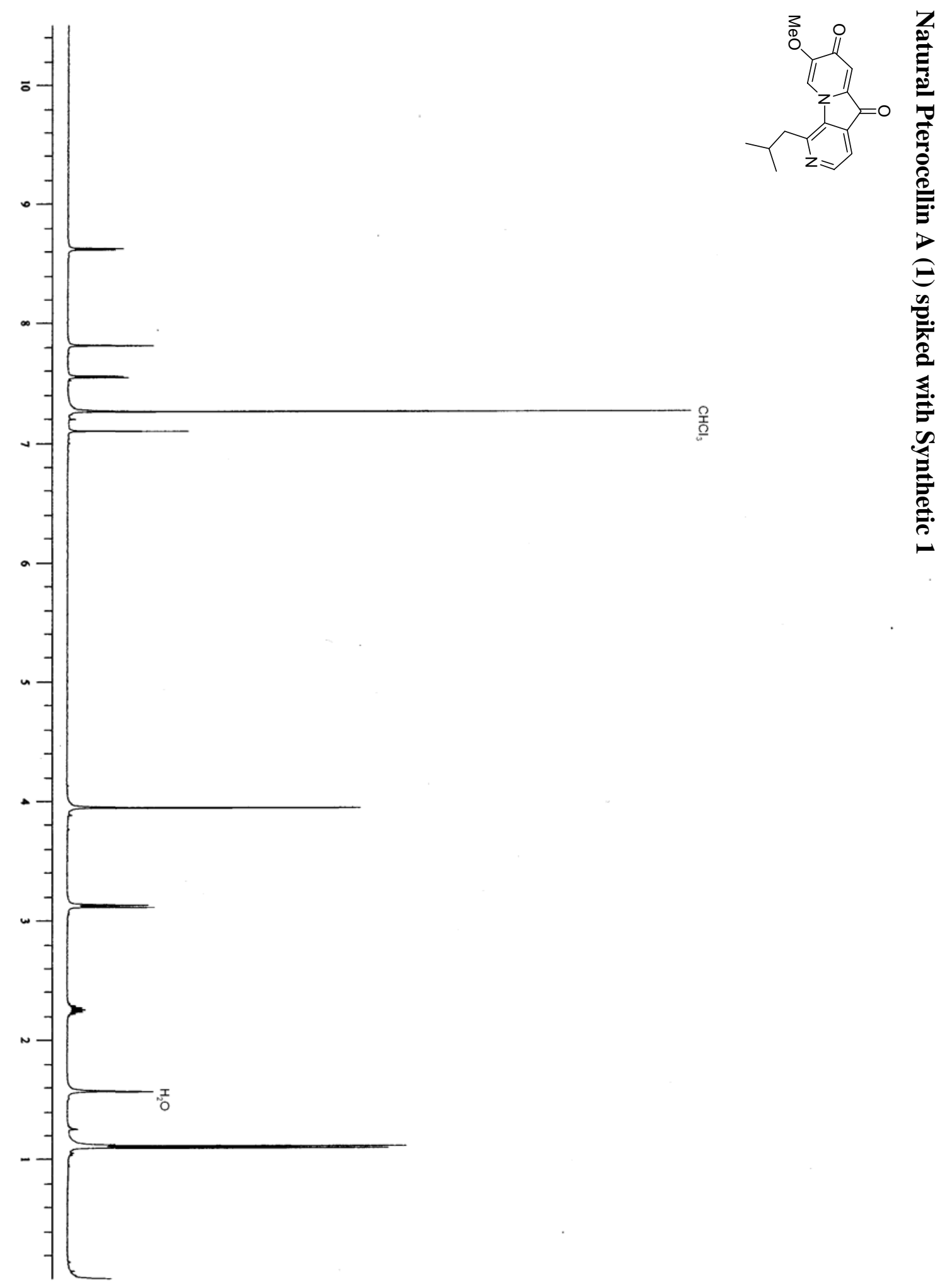


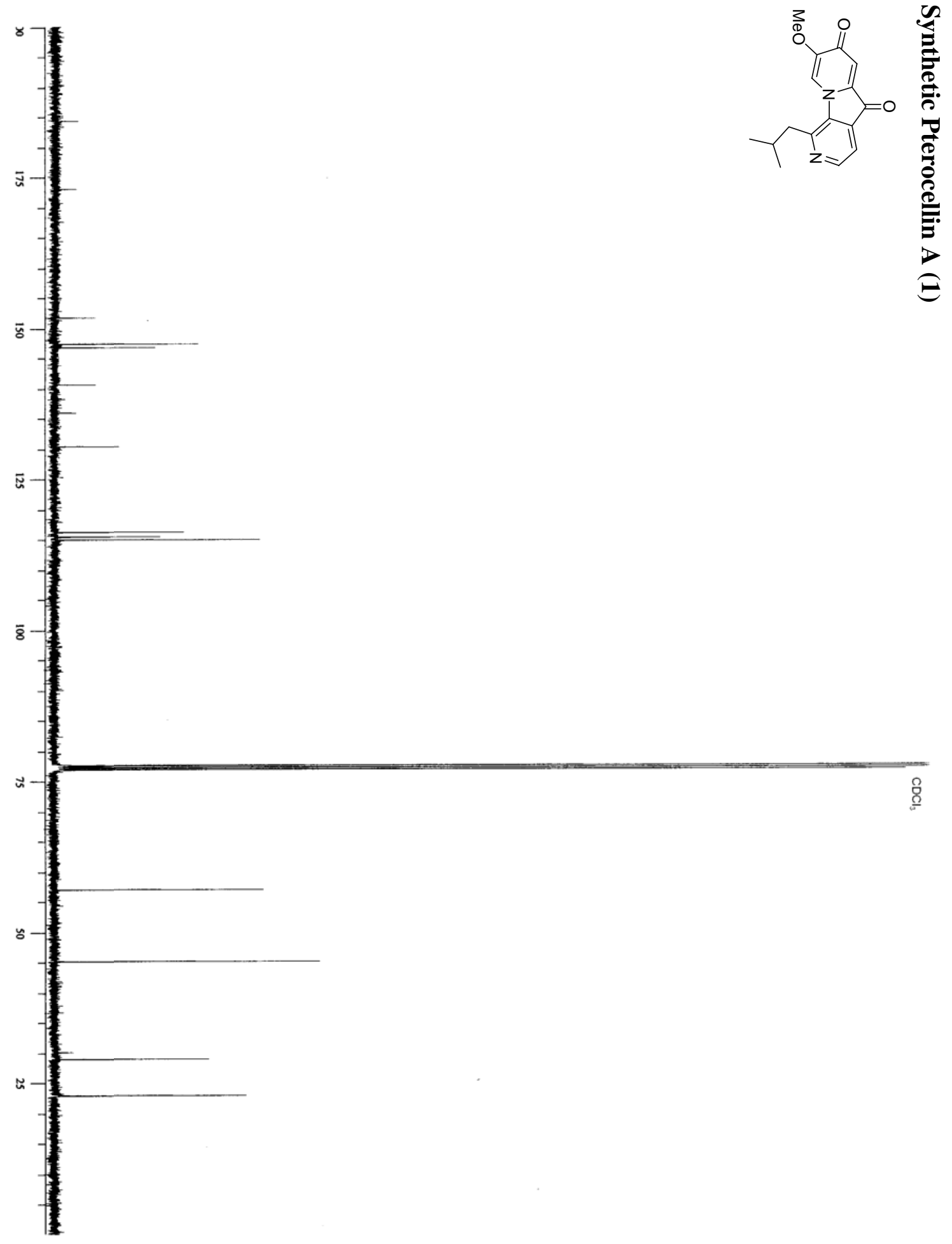

